\title{
GALVANIC TEST
}

- Acceleration Registrogram of Head Movement Induced by Galvanic Stimulation, and Galvanogram (Sekitani)-

By

ToRU SEKITANI

Department of Otolaryngology, Yamaguchi University, School of Medicine (Director: Prof. Shoichi HONJO)

The purpose of this investigation is to establish a galvanic test as qualitative and quantitative estimation method for the human equilibrium and to analyse mechanism of 'maintenance of equilibrium'. First, the intensity of galvanic stimulation is settled to be weak enough not to irritate the skin where the (bipolar and bi-retroauricular) electrodes are placed but to be strong enough to make a sway and falling reaction when the subject stands in Mann's position. A 10 second stimulation of 0.25 $\mathrm{mA}$ does not usually cause the swaying or falling reaction in normal subjects; $0.5 \mathrm{~mA}$ stimulation makes the half of them fall; $1.0 \mathrm{~mA}$ stimulation induces to fall quickly in most of all examinees. Secondly, recording of the swaying or falling movements caused by galvanic stimulation are performed by means of acceleration registration technique (Accelerometer $\rightarrow$ Strain meter $\rightarrow$ Oscillograph).

The falling times are plotted and expressed on the graphic scale which is similar to the "Calorigram", as author names it as "Galvanogram".

Otherwise, analyses of the curves of GAR are made as follows; 1) direction of swaying or falling movements of the body; 2) pattern of swaying, such as i) "initial wave", ii) upward or downward deflection, and iii) falling pattern

Twenty healthy adults are examined and the following results are obtained;

1) Short and small "initial wave to the cathode" is first observed on GAR immediately after galvanic stimulation $(0.5 \mathrm{~mA} \sim 1.0 \mathrm{~mA}, 3 \sim 5 \mathrm{~V})$, which usually appears at least within one second after stimulation is given.

2) Following immediately after the initial wave', swaying movements to the anode appear. Swaying and/or falling movements to the anode are almost always induced by $1.0 \mathrm{~mA}$ stimulation. Meanwhile, neither the stimulation of $0.25 \mathrm{~mA}$ induces any remarkable sway of the body nor "initial wave" on GAR.

3) No significant difference of falling time or GAR pattern between the stimulation given to the left and to the right is observed statistically in every different intensities of stimulation.

4) Average of falling time are 8.3 seconds in $0.25 \mathrm{~mA}$ stimulation: 4.4 seconds in $0.5 \mathrm{~mA}$; and 1.9 $\mathrm{sec}$ in $1.0 \mathrm{~mA}$ stimulation.

5) Accelerations of the head movements through the course of examination are $0.018 \mathrm{~g}$ in the Mann's position when they close their eyes; $0.03 \mathrm{~g}$ in the $0.25 \mathrm{~mA}$ stimulation; $0.056 \mathrm{~g}$ in $0.5 \mathrm{~mA}$; and 0.1 to $0.12 \mathrm{~g}$ at $1.0 \mathrm{~mA}$.

6) No side effect or discomfortable reaction is observed. 


\section{Galvanic test $の$ 研 究}

一一加速度記錄図法による電気性頭部動摇の

観察と Galvanogram の表現——

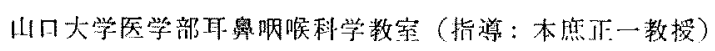

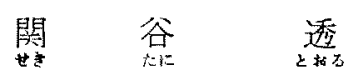

目次

稻言

万法上対象

1 対 急

I装留

1) 電気刺戟系

i) 直流電気刺戟装置

ii）電極と通電部位

iii) 通電と極性変㨦

2) 加速度計と装着へルメット

3) 坐測定器系

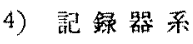

\section{相染勢}

N 検查条件の組合をと実施方法

付 1) 加速度記録图 (ARG)

2) 電気刺戟時加速度記録図(GAR)

GAR の例示

成 䅉

I GAR の通電值增加に上万所見

II転倒時間

1)枟倒時間の平均值と老の倍植限界

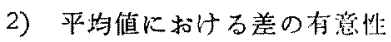

i) 電流值による差

ii）極性による差

iii）管勢（足位）による差

III 初発波

N GAR上の偋位と“振れ”

$V$ 副作用について

VI いわ奶る Galvanogram について

総括

考按

- 文献的事項 (主として Galvanic test の)

- 前庭反応誘発電流値について

・管極ならびに刺戥装置について

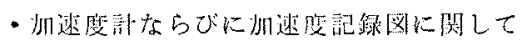

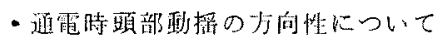

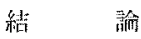

結㛭竞

主要交献

\section{緒言}

顛部に通電してメマイを生ずることは，1792 年Volta によつて報告されているが，さらに1803年 Ritter 並 びに Augustin は種々の疾患に対して“電気治療”を 施与し，その際，頭部に通電すると，メマイが誘発され ることについて夫々独自に研究報告しているとい5 ${ }^{28)}$. 1871 年 Hitzig 《曊部通電によつて眼球運動 (眼振) が 誘発されることを認め報告している. 以後それの生理学

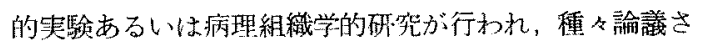
れてきた。

Fischer 1)によれば; Neumann (1907) が Galvanic test を前庭機能検查のための蹦休検查法として始めて 用い, 症例報告をして以来, Bárány (1907), Mackenzie (1917), Ruttin (1926), Brünings (1911) 等方回転检 查法，温度検查法と共に盛儿に応用したという。

以後 galvanic reactions に関する基礎的，臨休的虹 倹，覞察研究が本邦内外にてもかなり多数報告されてい たが，最近この方面での研究報告は意外に少い。

比較的采統的に研究報告さ机ているものについて述心 ると, Dix, Hallpike \& Spencer Harrison 12) (1949) のストレプトマイシン (SM) 中毒症例群に対する検榃 方法とその成績について。ささら Dix \& Hallpike ${ }^{14)}$ (1952) の Mèniére 氏病群とVestibular neuronitis 症 例群とについての報告がある。1949年には Ingelstedt \& Walander ${ }^{13)}$ がストレプトマイシン中毒例につい て行つた Galvanic test の成績を報告. 本邦では福 四他 25)（1962）方，第63回日本耳與咽喉科学会総会で “Galvanic test の一規蕉” と題して報告している，即 ち Galvanic test の梘準化を提唱し，一定電流值で刺 
战した際の眼振数を算兄，種々比較检討を加えている． そして正常，末梢迷路性，後迷路性の3つが鑑別できる のではないかと推詥している. 朴沢 24) (1961) は単桠単 耳法で刺㦸電流を漸次上昇させて眼振発来最少䦥值を求 め, Calorigram 類似の graph (Galvanogram) として 解析乙, 病的 Galvanogram には 2 型, 即ち 1 つは「感 受性低下型」であり，他は「方向優位性 (DP) を示す もの」であると説き，さらに電気性眼振の本態関して 臨床的考察を加えている。

增田 23) (1960) は Galvanic response を i) Mann 氏姿勢での転倒反応として，ii）遮眼書字検榃での偏 畫， iii）步行検査での偏歩として観察研究している. さらに Peitersen \& Zilstorff-Pedersen 18) (1963) は 歩行检查で通電後の偏歩について研究報告しているもの が見られる。

一方，1952 年 Jongkees と Groen 2) が感応コイルを 応用した一種の加速度計を頭部につけ，歩行時の頭部動 摇の様態を記録し，これを加速度記録四として研究開発 し，さらにこれを正常人ならびに患者について観察し て，著しい差のあることを確かめ，さらに加速度成分の 記録分析より，人の歩行運動時の迷路刺㦸の様式をらか がい，探索をはじめた。

わが国では北原 21)(1959）等がざらに感度のよい抵抗 線ヒズミ計器の一つとして実用化されてきた小型の非接 着抵抗線型直線加速度計をこの目的に応用し，種々の静 的，動的姿勢の頭部動摇を記録，検討し報告したのを燆 矢として前庭機能研究の領域にさらに取入れられる傾向 にある.

われわれる“より良き記録手段”としてこれに注目し ていたが，好都合なる小型計器の開発を見，早速身体頭 部動摇などの記録に応用しているものである。

電気刺战で誘発される前庭脊咀反射の発現は前庭眼反 射（いわゆる galvanic nystagmus）の発現に先行し， 且つはるかに弱い刺㦸で得られること16) 16) 28) 上り， 著者は身体（頭部）動摇を誘発し，それを加速度記録 図として他覚的客観的に記録し，その pattern を動摇 開始時間，転倒時間とともに波形の分析，加速度量の 測定に供し，さらにそれらの pattern の大略を一つの graphic scale (Galvanogram と呼称) に描記すること で，前庭機能の様態を質的量的に表現観察することを試 み，Galvanic test の一変法を考案研究してきた。

本篇では，その方法と健康成人について行つた成績を 述べ，考察を加える，

\section{方法と対象}

\section{I 対 象}

本邦䛧:康成人 20 名（年令 $18 \sim 30$ 才。.内1名 50 才） を選んだ．これらのものは既往歴に耳疾患，メマイがな く，耳鏡検相で異常を認めず，四胶運動機能の正常な， かつ身体平衡失調を認めないるのである。

II 装置

ブロックーダイフグラムNo.1 (第1 图) の右半図に 示与通り，1）直流電気刺战装置，2）加速度計と装着 ヘルメット、3) 歪測定器,ならびに 4) 記録器よりな る。 その各部の性能および使用法を概説する。

1) 電気刺㦸系

i) 直洗電気刺㦸装置

教室の野中の考案した装置を使用した、その実物なら

第1图 Block Diagram No. 1

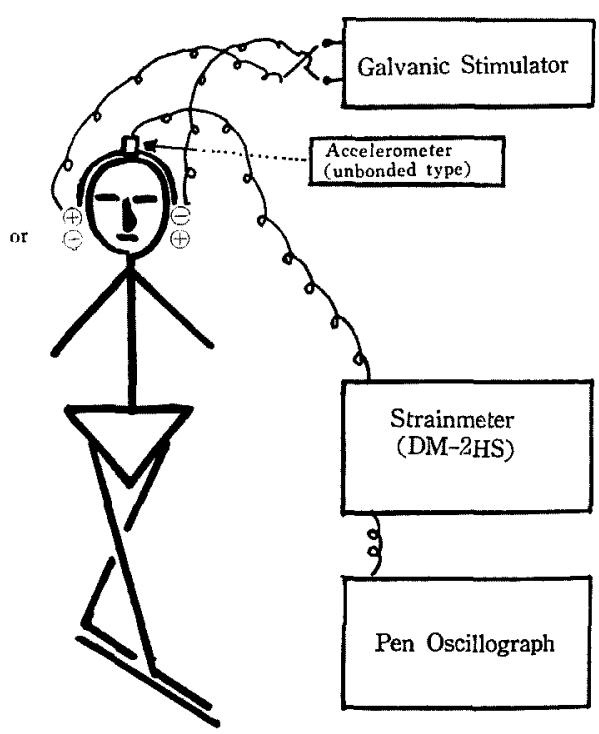

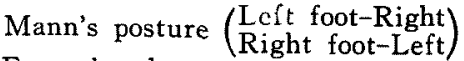

Eyes closed

Block Diagram No. 2

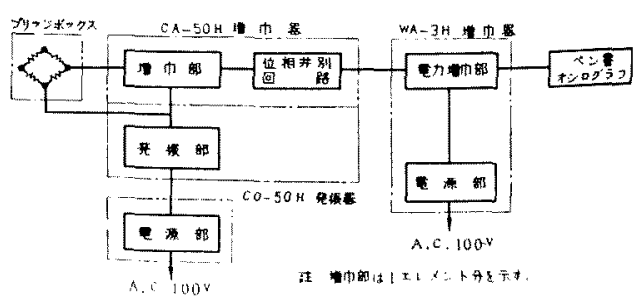


第 2 図值流電気刺戟装置とその配線図
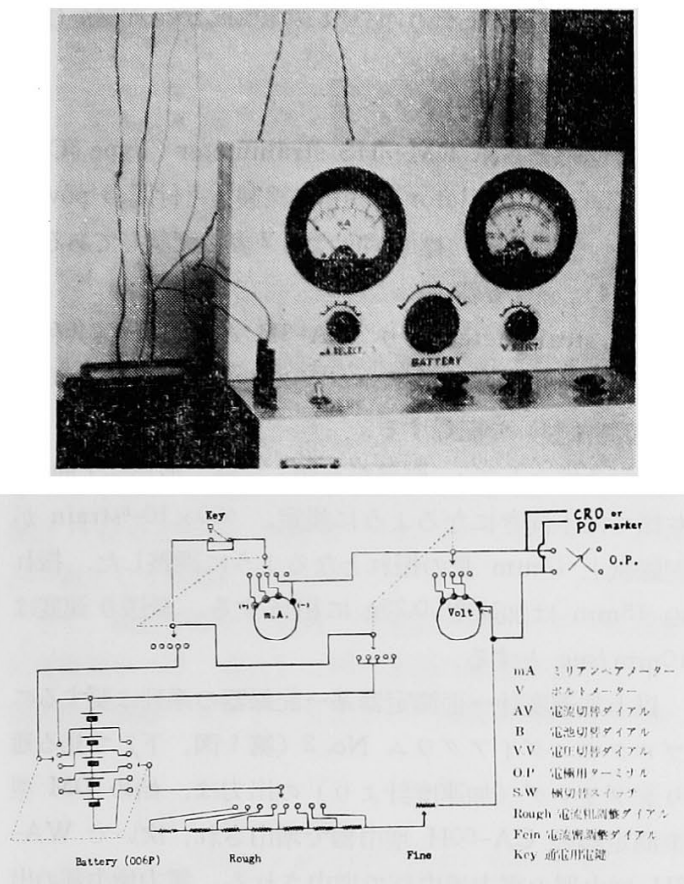

びに配線図は第2 2 図に示す。この一部に，刺㦸用 $\mathrm{SW}$ を記録器の marker 用ペンと直列に入れるようにした. 配線図に示されるように Transister Battery (006P) 9 volt 5 コを直列に 内蔵する，毎時，使用に先立ち雹 池電圧を検定して 刺㦸の一定を四る.なお，使用後は Battery charger (Type TR-1 “FULMITER” Use for BL-006P9V (NIHON SEKISO Dry Battery Ind. Co. Ltd)] によつて充電して使用する.

ii) 電極と通電部位

電極は中凹久久銀板電極 (Concave silver disc), 直径 $10 \mathrm{~mm}$ ，を 2 二用い，双極両耳後（第3図）で置く，接 触抵抗を下げ，通電性をよくするために以下の手順を行 5. Silver disc を sand paperを使つて磨き, アルュー ルで清拭する.心電図用電極糊（福田エレクトロ製）を 銀板の凹面につける. 一方, 両耳後部はアルコール・カ 一ゼで良く清拭し，できるだけ乾かすようにする。ここ に電極を紏々う霄で固定する。なお，この際テスターを 用いて接続各部の通電の良否を検討すると同時に抵抗值 を読みとり記録する．抵抗は 10～20K 以下であるこ とが望ましい. $40 \mathrm{~K} \Omega$ 以上の時には，0.1〜0.2mA を数 10 秒間通電すると抵抗值は下つてほぼ一定となり，好 条件が得られることが多い。
第 3 图電㥛の部位（双㥛両耳後法）

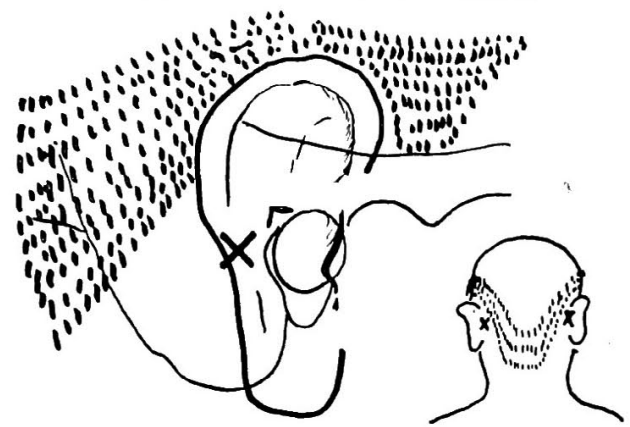

iii）通電操作と極性変換

上述のようにセットしたのち, 続いて以下の如く操作 して後, 通電検查に入る.

（1）刺㦸装置 OP に電導子をつける（勿論，電極は 両耳後部に既に貼付してある).

(2) SW と+側，一側をたしかめる.

(3) Keyをおし, Ampere-meter と Volt-meter の針のフレを読み, rough と fine の dial を迴して所 定の刺㦸電流值が出るように加減する. 決つたら Key をはずして，その時得られる $\mathrm{mA}$ 值，Volt 值をそれぞ れ記録する。

（4）次いで被検者に目的の姿勢をとらせ，検査に入 る.

（5）刺㦸 SW ボタンを押す 刺㦸電流が 入れば同 時に記録紙上にマークされる。

通電は 10 秒間行5.もし 10 秒以内に被検者が転倒与 れば，直ちに電流を切る. その後は 1 2 分以上の休止 の後,

（6）同じ電流值で極性を変えて行う（極性変換 SW によつて容易に変え得る). 以上で同じ電流値にて左右 それぞれ通電検査をしたことになる。

次いで (3) の方法に従つて電流值を增减して 所定の 刺㦸值を得る。そして（4）(5)（6）の順に検査を進め る.

2）加速度計と装着ヘルメツト

非接着 抵抗線型加速度計（120A-ID 型）（共和與線 製）(第 4 図左前面）を用いた。これの標準定格值は表 の通りである(第1表).

計器 (加速度計) が頭部に良く固定された状態を得る ためにへルメット（プラスチック加工で軽量なるの）の 頂上で矢状面に切込みをつくり，その中に加速度計を楩 入固定した（第 5 図），検査の時このヘルメットをかぶ 
第 1 表 加速度計の定格値

\begin{tabular}{|c|c|c|c|c|c|}
\hline 型 & $\begin{array}{l}\text { 容 } \\
( \pm g)\end{array}$ & $\begin{array}{c}\text { 公称ブリ } \\
\text { ジ抵抗 } \\
(\Omega)\end{array}$ & $\begin{array}{l}\text { 固有振 } \\
\text { 動 数 } \\
(\mathrm{c} / \mathrm{s})\end{array}$ & $\begin{array}{c}\text { 最大入 } \\
\text { 力電压 } \\
(\mathrm{v}) \\
\text { (v) }\end{array}$ & $\begin{array}{c}\text { 聚大出 } \\
\text { 力電压 } \\
(\mathrm{mV} / \mathrm{g})\end{array}$ \\
\hline $120 \mathrm{~A}-1 \mathrm{D}$ & 1 & 120 & 22 & 5 & 10 \\
\hline
\end{tabular}

第 4 図非接着抵抗線型加速度計（Accelerometer, unbonded type) ( ) 歪测定器とその電 源部

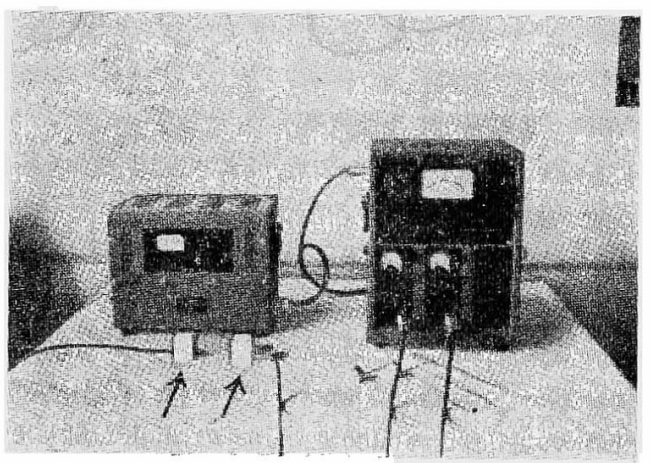

第25:図要加速度計を装着したヘルメット 右前面以銀板電極を見る(

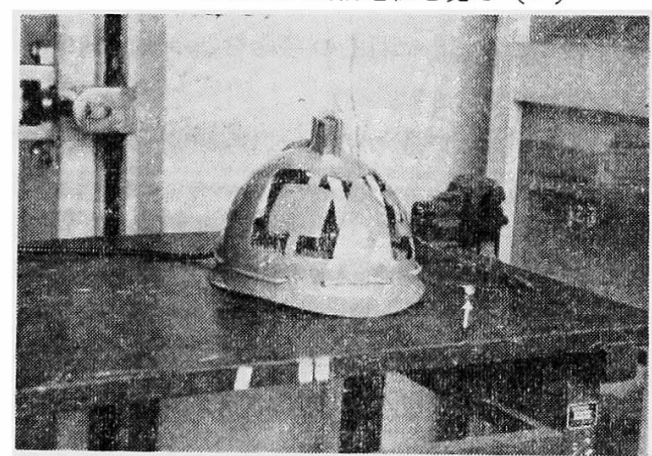

第 2 表 歪測定器の標準感度

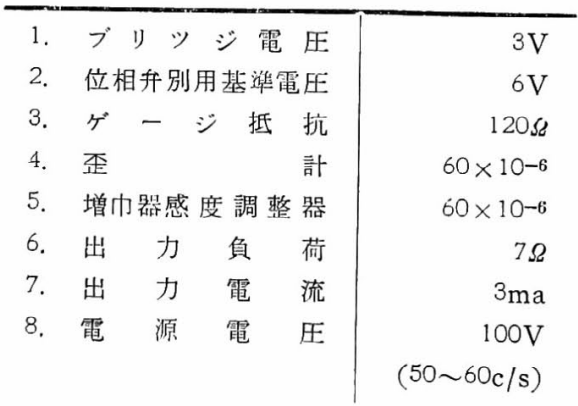

り，顎紐で緊䋠することで容易に頭部に固定し得る。 れで頭部動摇の 左右方向への 加速度成分の 記録が行兄 る。

3) 丕測定器系

第 4 図のように DM-2HS strainmeter (Type 3CO$50 \mathrm{H}$ Carrier oscilator) (共和無線製) と付属の power supply を用いる。標準感度は籘 2 表に記载してある.

4) 記 録器系

上記 strainmeter より WA-3H Amplifier（共和電 業製）を通してペン書きオシログラフ（WR 211-3C) （渡辺測器製）で記録する。

記録条件として：頭部が右傾した時，波形は上向き， 左傾では下向きになるよらに規定．600×10-6 strain が 記録紙上 $15 \mathrm{~mm}$ 長の振れとなるように調整した，振れ の $15 \mathrm{~mm}$ は加速度 $0.25 \mathrm{~g}$ に相当する。紙送り速度は $10 \mathrm{~mm} / \mathrm{sec}$ とする.

以上加速度計 $\rightarrow$ 卒测定器系 $\rightarrow$ 記録器の系列は要するに プロック ダイアグラムNo. 2 (第 1 図，下）で見る通 り；ブリッヂ（加速度計より）の出力は，始め DM 型 歪測定器の $\mathrm{CA}-50 \mathrm{H}$ 增巾器で增巾され, 次いで WA$3 \mathrm{H}$ 增巾器の電力增巾部で增巾される。電力增巾部の出 力は外部に取出され，ペン書きオシログラフに接続ざ れ，そこでオシログラフのガルバノィーターを動かし， 記録される。

$$
\text { III姿 勢 }
$$

第1 図のブロック ダイアグラムNo.1 に示すよう に Mann 氏姿勢, 閉眼で行つた，足は一直線上に前後 に，すなわち左足が前に右足先が左足の踵に触れるよう 飞並べて立つ（以下左足前と呼ぶ）姿勢をとらせる. 前 後の足を资代する (右足前)。な打転倒状態，時間をは つさりさせるために，高さ約 $10 \mathrm{~cm}$ の方形の踏石を利 用し，その上にて目的の姿勢をとらせる。

\section{IV 検査条件の組合せと実施方法}

Fischer 1), 增田 23) の実験成績お゙よび著者の行つた予 備実験の成績より, 刺㦸電流値を $0.25 \mathrm{~mA}, 0.5 \mathrm{~mA}, 1.0$ $\mathrm{mA}$ の 3 種とした. この規定した 3 種の刺㦸量に対する 反応の様子を検討し，前庭迷路機能を追求することにし た.

第3表の如く，椧査条件の組合せを作る。すなわわ， 通電検查の前に Mann 氏姿势閉眼にしただけの状態の 時のものを一種とり, Control とし検查進行上の見通し に役立たせる. そして 3 種の刺战電流値と電極々性とよ り組合せを 6 種類作る。すなわち計 7 枚の記録をとる. 
第 3 表 検査条件の組合せ

\begin{tabular}{|c|c|c|c|c|}
\hline \multicolumn{2}{|c|}{ 警 } & 答 & 電極憻性 & 能流伯 \\
\hline 1. & t足 & 閉腿（右足前） & ナ シ & ナ シ \\
\hline 2. & " & 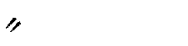 & 不一在十 & $0.25 \mathrm{ma}$ \\
\hline 3. & " & " & , & 0.5 \\
\hline 4. & " & " & " & 1.0 \\
\hline 5. & " & " & 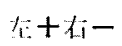 & 0.25 \\
\hline 6. & " & 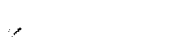 & " & 0.5 \\
\hline 7. & " & " & " & 1.0 \\
\hline
\end{tabular}

さらに Mann 氏姿勢での前後足の交代によつて2 倍,

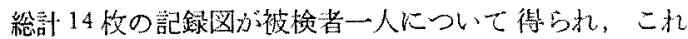
が一組しして観察に供される。

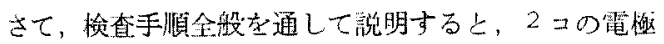

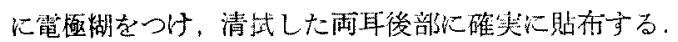

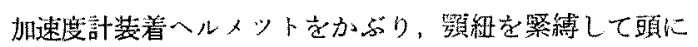

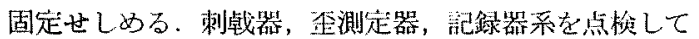

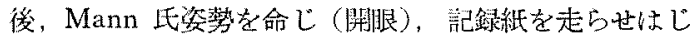

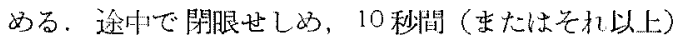

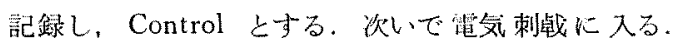
Mann 氏姿勢閉眼で $0.25 \mathrm{ma}$, 左十在一の桠性で 10 秒間

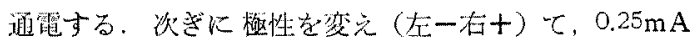
で 10 秒間通笔与る。このようにして $0.5 \mathrm{~mA}, 1.0 \mathrm{mAK}$ いてもとれでれ们ら。

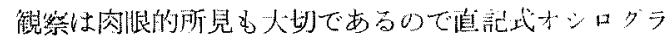
フの長所家活かして刻々の将化をできるたけ克明心おシ ロペーハに記入していく.

代 1 , 加速度記録図

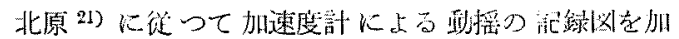
速度記録图 (莫钊 して Acceleration registrogram

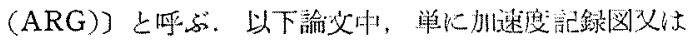

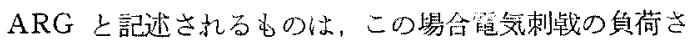
れない時の頭部俱摇の記録图を指す。

第 6 図 GAR 例示

CHS No. $128 \hat{0}$

Mann's posture (Left foot-Right)

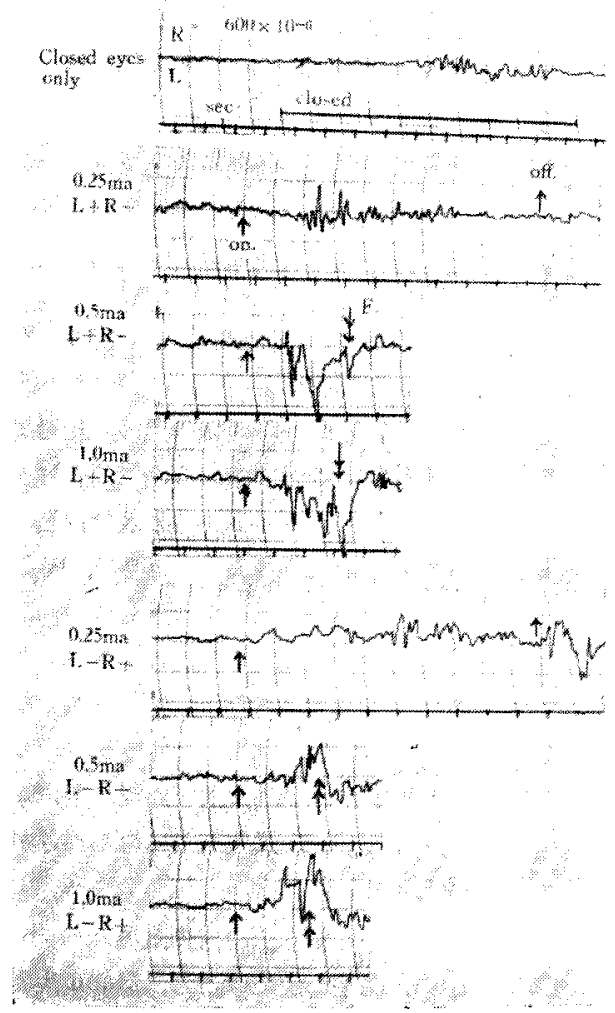

Mann's posture (Right foot-Left)
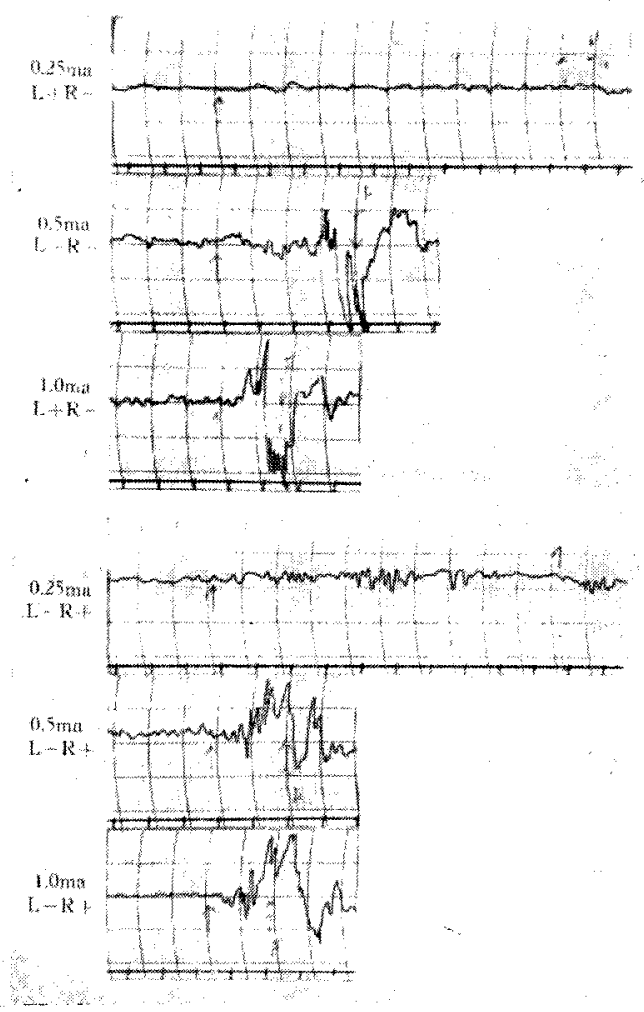
第 7 図 GAR の例示

CHS No. 5218

Mann's posture (Left foot-Right)

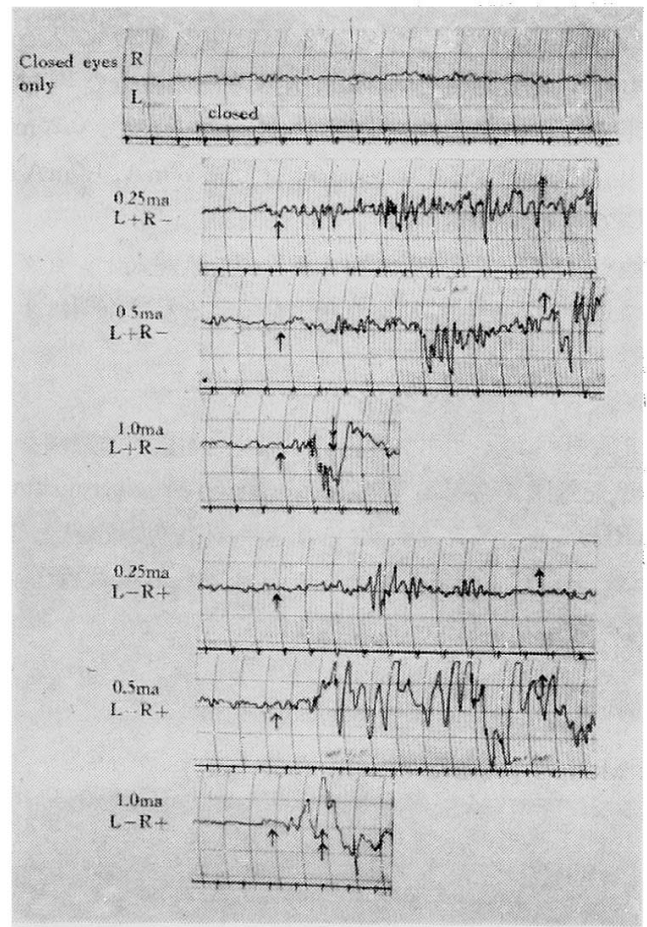

NOTE

(Left foot-Right): Left foot in front of right foot and vice versa

$\widetilde{\hat{i}}$ : Current on

$\hat{\imath}$ : Current off

: Fall to left side, and current off

$\tilde{i}$ Fall to right side, and current off

\section{位2. 電気刺㦸時加速度記録図}

双極両耳後法で電気刺韩を加えて誘発される身体頭部 動摇の加速度記録図を意味し, Galvanoacceleroregistrogram (以下 GAR と略記) と呼称する, 前記の ARG と区別する. GAR 上，身体頭部に認をべき動摇のない 状態の時に描かれる線状波を基線とする。

健康成人では Mann 氏姿勢開眼時には殆えど基線の 政摇はない，閉眼によつて，個人個人によつて若干基線 の動摇が見られるが，一方に偏することは少い（第6 図, 第 7 図).

GAR についてたたる微察点した；

(1) 忶倒の有無:
(2) 枟倒するまでの封閂

(3) 忶倒方向

（4）頭部動摇の状態䋂過などである.

\section{成樍}

健康成人 20 名について Galvanic test（特に本法を GAR test と呼ぶ）を行い，下記の諸成績を得た

I 通灭檤增加に上る GAR 所見

GAR 波形は通管によつて（第6 6 図，第 7 図参照), 最初陰橔側へひか水るように小さい1 つの動摇を示し，

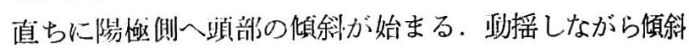
がつづく場合は数コの反傾斜側向き棘波を出すこのと き被検者は立位を保つか又は転倒する，電流を切ると反 傾斜側（陰極側）一反撥性见動摇し，時に転倒するもの がある。

刺㦸の增大によつてこれらの傾向が顕著となる.

i） $0.25 \mathrm{~mA}(1 \sim 4 \mathrm{volt})$ 通電刺㦸洔は軽度または中等 度の頭部動摇をきたし，波形上，棘波をなすことがある が，枟倒することは少い，基線は陽極側へ偏位する傾向 を示す 通常その動摇は 5〜 7 秒まで以後は動摇冲少く， 小さくなり，偏位も回復する傾向がある。

ii） $0.5 \mathrm{~mA}$ (1.5〜 6volt) では中等度の動摇をきたし， 棘波が大きく且つ多くなり，基線の偏位も大きい(陽椣 側一). 初発波 (後述) が出現する. 動摇, 傾斜ととも に転倒するものがある.

iii) $1.0 \mathrm{~mA}(2.0 \sim 10 \mathrm{volt})$ では，動摇待激しく，急速 に陽極側一傾斜，転倒する．初発波が見られる．時に局 所痛を訴えることがある.

』枟倒時間

枟倒現象，転倒時間については肉眼的にも観察，湘定 することができるが，GAR によつて，はつきりと記録 保存され，左あるいは右耳刺㦸時の転倒現象の経過なら びに時間について比較し得るものである.

転倒時間を一覧表とした (第 4 表)．分散分析その他 統計学的処理を行らため転倒しなかつた例には10なる 数值を入れた，これらを姿勢，極性を考虑しつつ，電流 值を縦軸に，洔間を横軸としたグラフ上にプロットし てみると, $0.25 \mathrm{~mA}$ の場合, 10 秒以上, 即ち転倒しない ものが大部分（20 例中 14 例，70\%）を占める. 一方， $1.0 \mathrm{~mA}$ 刺㦸では転倒時間は 2 秒前後汇集中し, 全例転到 していることがわかる. $0.5 \mathrm{~mA}$ 通電時ではばらつきがか なり強い（符8図1.2.).

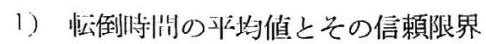
第 5 表に示扵如く，総平均值でみると，Mann 氏姿勢 
第 4 表 Falling Time of Clinically Healthy Subjects (20 adults)

\begin{tabular}{|c|c|c|c|c|c|c|c|c|c|c|c|c|c|}
\hline \multirow{3}{*}{\multicolumn{2}{|c|}{$\begin{array}{l}\text { Posture: } \\
\text { Polarity: } \\
\text { Intensity: } \\
\text { IS-No. Age }\end{array}$}} & \multicolumn{6}{|c|}{ Left foot in front of right foot } & \multicolumn{6}{|c|}{ Right loot in front of left foot } \\
\hline & & \multicolumn{3}{|c|}{$L-R+$} & \multicolumn{3}{|c|}{$\mathrm{L}+\mathrm{R}-$} & \multicolumn{3}{|c|}{$L-R+$} & \multicolumn{3}{|c|}{$\mathrm{L}+\mathrm{R}-$} \\
\hline & & 0.25 & 0.5 & $1.0 \mathrm{ma}$ & 0.25 & 0.5 & $1.0 \mathrm{ma}$ & 0.25 & 0.5 & $1.0 \mathrm{ma}$ & 0.25 & 0.5 & $1.0 \mathrm{ma}$ \\
\hline 1. & 28 & 10 & 2.8 & $\begin{array}{l}\sec \\
2.5\end{array}$ & 10 & 3.5 & $\begin{array}{l}\sec \\
3\end{array}$ & 10 & 2.2 & $\begin{array}{l}\mathrm{sec} \\
1.8\end{array}$ & 10 & 4 & $\begin{array}{l}\mathrm{sec} \\
1.8\end{array}$ \\
\hline 2. & 24 & 10 & 4.6 & 2 & 10 & 6 & 2.2 & 10 & 5 & 1.8 & 10 & 4 & 1.8 \\
\hline 3. & 26 & 10 & 1.8 & 1.9 & 10 & 3.2 & 1.8 & 10 & 2.5 & 1.8 & 10 & 3 & 2 \\
\hline 4. & 26 & 10 & 10 & 1 & 8 & 3.5 & 1 & 10 & 3 & 1.2 & 5 & 2.5 & 1.5 \\
\hline 5. & 21 & 10 & 10 & 2 & 10 & 10 & 2 & 10 & 4 & 2 & 10 & 5 & 2 \\
\hline 6. & 28 & 5.6 & 4.6 & 2.5 & 6 & 2,6 & 2 & 7.5 & 3 & 2 & 4 & 4 & 2.5 \\
\hline 7. & 19 & 4.6 & 2 & 1.8 & 10 & 3 & 2 & 4 & 2.5 & 2 & 10 & 3 & 2.5 \\
\hline 8. & 25 & 10 & 2 & 2 & 8 & 2 & 1.8 & 5 & 2.8 & 1.8 & 5.4 & 1.6 & 1.6 \\
\hline 9. & 26 & 8 & 3 & 1.4 & 7.5 & 2 & 1.8 & 7 & 2.6 & 1.6 & 5 & 2 & 1.8 \\
\hline 10. & 24 & 10 & 10 & 1.2 & 10 & 4.2 & 1.8 & 10 & 10 & 2 & 10 & 3.2 & 3.0 \\
\hline 11. & 28 & 4 & 3 & 2.5 & 10 & 6 & 2.5 & 3 & 3 & 1.8 & 10 & 10 & 2 \\
\hline 12. & 21 & 10 & 3 & 2 & 8 & 4 & 2 & 10 & 4 & 2.5 & 10 & 6 & 4 \\
\hline 13. & 20 & 10 & 4.4 & 2 & 10 & 4 & 1.8 & 10 & 6 & 1.8 & 10 & 8 & 2 \\
\hline 14. & 23 & 10 & 10 & 1.7 & 10 & 3.2 & 1.8 & 10 & 10 & 2.4 & 10 & 4.4 & 2 \\
\hline 15. & 22 & 3 & 1.8 & 1.5 & 10 & 10 & 1.0 & 4 & 2 & 1.2 & 10 & 2.8 & 1.2 \\
\hline 16. & 22 & 10 & 2.2 & 1.6 & 10 & 2.2 & 1.7 & 10 & 2.6 & 1.7 & 10 & 10 & 2.8 \\
\hline 17. & 22 & 10 & 10 & 2 & 10 & 4 & 2 & 10 & 10 & 2 & 10 & 2.5 & 1.0 \\
\hline 18. & 50 & 10 & 4 & 2.5 & 3 & 2.4 & 1.7 & 10 & 2 & 1.6 & 4 & 3.6 & 3.1 \\
\hline 19. & 26 & 6 & 3.3 & 2 & 10 & 5 & 2 & 7 & 2.6 & 1.6 & 10 & 4.4 & 1.8 \\
\hline 20 & 28 & 10 & 10 & 2.3 & 3.2 & 2.2 & 1.8 & 2.6 & 2.4 & 1.8 & 4 & 3 & 1.8 \\
\hline & & 8.6 & 5.2 & 1.9 & 8.7 & 3.3 & 1.8 & 8.0 & 4.1 & 1.8 & 8.0 & 4.4 & 2.0 \\
\hline
\end{tabular}

註：分散分析なと統訃的処理を行うため転倒しなかつた例については仮に10なる数值を入れた。

第 5 表 Falling Time of GAR Test

- Mean value and their confidence limit-

a) Mean Value

\begin{tabular}{c|c|c|c|c}
$\begin{array}{r}\text { Posture \& } \\
\text { Polarity }\end{array}$ & \multicolumn{2}{|c|}{ Left foot-Right } & \multicolumn{2}{|c}{ Right foot-Left } \\
\cline { 2 - 4 } Intensity & $\mathrm{L}-\mathrm{R}+$ & $\mathrm{L}+\mathrm{R}-$ & $\mathrm{L}-\mathrm{R}+$ & $\mathrm{L}+\mathrm{R}-$ \\
\hline $0.25 \mathrm{ma}$ & $8.6 \mathrm{sec}$ & $8.7 \mathrm{sec}$ & $8.0 \mathrm{sec}$ & $8.0 \mathrm{sec}$ \\
0.5 & 5.2 & 3.3 & 4.1 & 4.4 \\
1.0 & 1.9 & 1.8 & 1.8 & 2.0
\end{tabular}

b) Their Confidence limit ( $\alpha=0.05)$

\begin{tabular}{c|c|c|c|c}
\hline \begin{tabular}{r} 
Posture $\begin{array}{c}\text { Polarity } \\
\text { Intenfity }\end{array}$ \\
\cline { 2 - 4 }
\end{tabular} & \multicolumn{2}{|c|}{ Left foot-Right } & \multicolumn{2}{c}{ Right foot-Left } \\
\hline $0.25 \mathrm{ma}$ & $7.5 \leqq \mathrm{~m} \leqq 9.7$ & $7.7 \leqq \mathrm{~m} \leqq 9.7$ & $6.7 \leqq \mathrm{~m} \leqq 9.3$ & $6.4 \leqq \mathrm{~m} \leqq 9.6$ \\
0.5 & $3.6 \leqq \mathrm{~m} \leqq 6.8$ & $1.6 \leqq \mathrm{~m} \leqq 5.0$ & $2.8 \leqq \mathrm{~m} \leqq 5.4$ & $3.3 \leqq \mathrm{~m} \leqq 5.5$ \\
1.0 & $1.7 \leqq \mathrm{~m} \leqq 2.1$ & $1.7 \leqq \mathrm{~m} \leqq 1.9$ & $1.7 \leqq \mathrm{~m} \leqq 1.9$ & $1.5 \leqq \mathrm{~m} \leqq 2.5$
\end{tabular}


筹8图枟倒時間について（健康成人 20 名）

1. Mann 代登努（在足访）閉恨時：

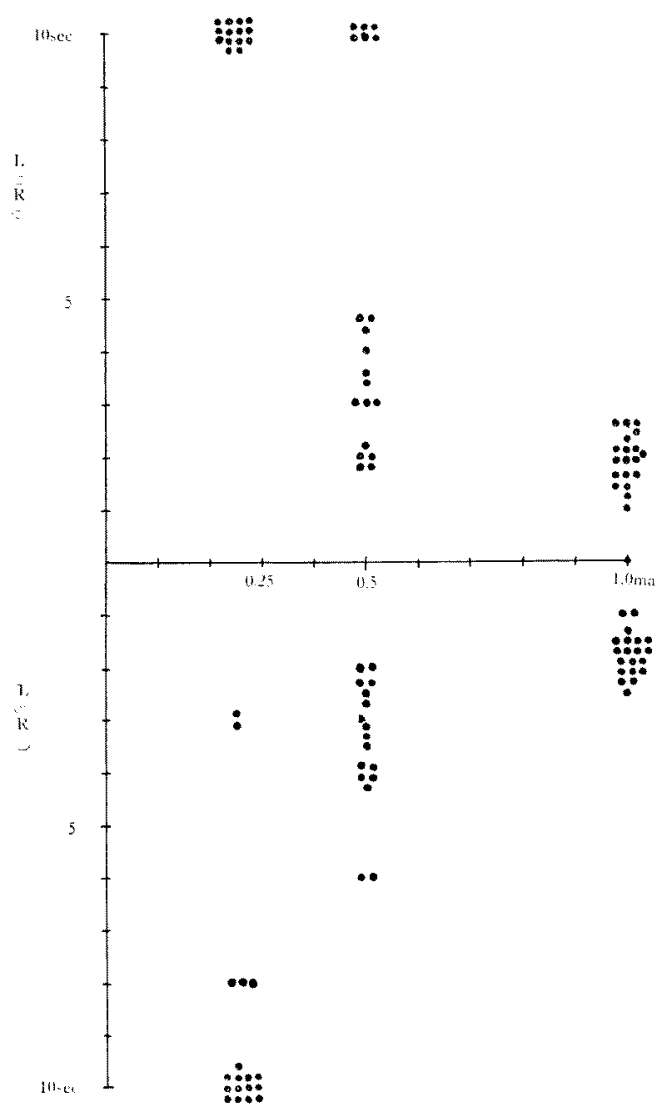

閉眼で $0.25 \mathrm{~mA}$ 負荷の時の枟倒時間は 8.3 秒以上， 0.5 $\mathrm{mA}$ では 4 秒，1.0 mA では 2 秒前後である.

2) 平均値に打ける差の有意性

こ扎ら各条件下の平均值について各種条件每に差の有 意性を検定した。

i) 電流值の差による美:

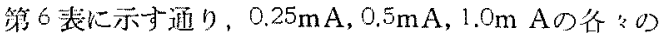

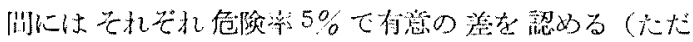
し， $0.5 \mathrm{~mA}$ と $1.0 \mathrm{~mA}$ とでは部分的に“やや有密”之の 所見を得ている).

ii）極性による差

第 7 表の通り，極性を左右に变えること，即ち左耳刺

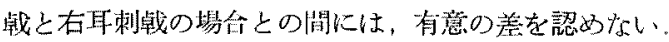

iii) 姿荶(足位) に上る差

第8表の通りである。平均值の上では差があるよらに
2. Mann 氏登誃（右足前）閶顺時：

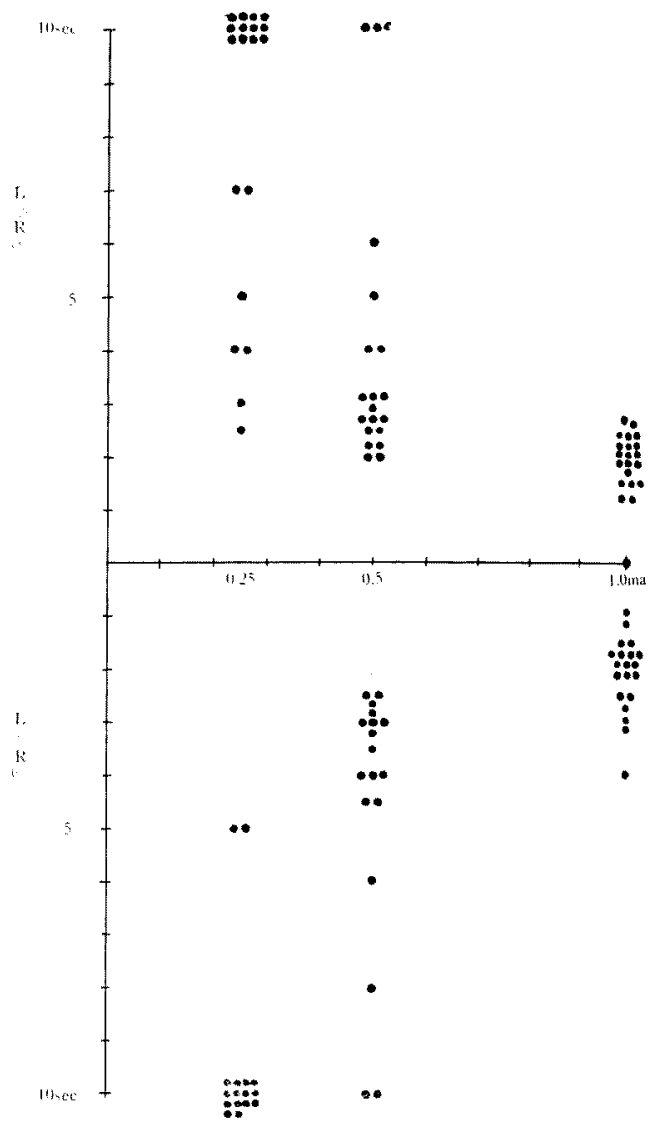

思われたが，美の検定の結果，有意性は誌められなかつ た、すなわb通雪によつて陽極側への転倒反応を誘発さ れる本法にあつてはいずれの侧の足る前にしても有意の 差がないと推論される。

$$
\text { III“初発波” }
$$

0.25mA 刺㦸の場台にはさほど著明でないるのるある

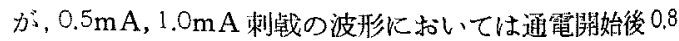
〜0.6〜0.4 秒に陸極㑬へ问5小さい波をはつきり見るこ とができる。この波が GAR 波形の中で最初に現われ る波であるので初発波（Initial wave）と名优く，肉脚 的観察では，看過される程の学化，動摇であり，被検者 の大部分は自觉しない，筧者の知る限りでは，いわゆる 前逶反射としての頭部動摇に関する論文中，初発波に関 する記述を見ない。

初発波の性筫は（1）陰極側すなわち反傾斜側へ向つ 
第6 表 Falling Time

-Comparison of the Difference of Mean Value owing to each intensity-

\begin{tabular}{|c|c|c|c|}
\hline \multirow[b]{2}{*}{$\begin{array}{l}\text { Posture \& } \\
\text { Intensity } \\
\end{array}$} & \multicolumn{2}{|c|}{ Compared between } & \multirow{2}{*}{$\begin{array}{l}t=2.932 \\
(\alpha=0.05)\end{array}$} \\
\hline & Groups & $\begin{array}{l}\text { their } \\
\text { Mean }\end{array}$ & \\
\hline \multicolumn{4}{|l|}{ Left foot-Right } \\
\hline $\mathrm{L}-\mathrm{R}+$ & $0.25: 0.5$ & $8.6: 5.2$ & $t=3.685^{* *}$ \\
\hline " & $0.25: 1.0$ & $8.6: 1.9$ & $\mathrm{t}=12.154 * * *$ \\
\hline$"$ & $0.5: 1.0$ & $5.2: 1.9$ & $\mathrm{t}=4.396 * *$ \\
\hline $\mathrm{L}+\mathrm{R}-$ & $0.25: 0.5$ & $8.7: 3.3$ & $t=5.804 * *$ \\
\hline " & $0.25: 1.0$ & $8.7: 1.8$ & $\mathrm{t}=13.774 * * *$ \\
\hline " & $0.5 \quad 1.0$ & $3.3: 1.8$ & $t=1.895 *$ \\
\hline \multicolumn{4}{|l|}{ Right foot-Left } \\
\hline $\mathrm{L}-\mathrm{R}+$ & $0.25: 0.5$ & $8,1: 4.1$ & $t=4.623 * *$ \\
\hline " & $0.25: 1.0$ & $8.1: 1.8$ & $\mathrm{t}=10.179 * * *$ \\
\hline$"$ & $0.5 \quad 1.0$ & $4.1: 1.8$ & $\mathrm{t}=3.757 * *$ \\
\hline$L+R-$ & $0.25: 0.5$ & $8.0: 4.4$ & $t=3.833 * *$ \\
\hline " & $0.25: 1.0$ & $8.0: 2.0$ & $t=7.514 * * *$ \\
\hline$"$ & $0.5 \quad 1.0$ & $4.4: 2.0$ & $t=4.131 * *$ \\
\hline \multicolumn{4}{|c|}{$\begin{array}{l}\text { * statistically not significant } \\
\text { ** significant }\end{array}$} \\
\hline
\end{tabular}

第 7 表 Falling Time

- Comparison of the Difference of Mean value owing to "Polarity reversed"-

\begin{tabular}{|c|c|c|c|}
\hline \multirow{2}{*}{$\begin{array}{r}\text { Posture \& } \\
\text { Intensity } \\
\end{array}$} & \multicolumn{2}{|c|}{ Compared between } & \multirow{2}{*}{$\begin{array}{l}t=2.032 \\
(\alpha=0.05)\end{array}$} \\
\hline & Groups & Mean & \\
\hline Left foot-Right & & & \\
\hline 0.25 & $\mathrm{~L}$-*: $\mathrm{R}$-** & $8.6: 8.7$ & $t=0.136^{*}$ \\
\hline 0,5 & $\mathrm{~L}-\mathrm{R}-$ & $5.2: 3.3$ & $\mathrm{t}=1.752 *$ \\
\hline 1.0 & $\mathrm{~L}-\mathrm{R}-$ & $1.9: 1.8$ & $\mathrm{t}=0.084 *$ \\
\hline
\end{tabular}

Right foot-Left

$0.25 \mathrm{~L}-\mathrm{R}-\quad 8.0: 8.0 \mathrm{t}=0.101$ *

$0.5 \quad \mathrm{~L}-\mathrm{R}-4.1 \cdot 4.4 \mathrm{t}=0.369 *$

$1.0 \quad \mathrm{~L}-: \mathrm{R}-1.8: 2.0 \mathrm{t}=0.089 *$

* "L-" means "Negative" electrode on the left mastoid and "Positive" on the right mastoid.

** " $R$-" means "Negative" on the right mastoid and "Positive" on the left mastoid.

* not significant

** significant
筑 8 表 Falling Time

- Comparison of the Difference of

Mean Value owing to Posture

(condition of foot position)--

\begin{tabular}{|c|c|c|c|}
\hline \multirow[b]{2}{*}{$\begin{array}{l}\text { Polarity \& } \\
\text { Intensity } \\
\end{array}$} & \multicolumn{2}{|c|}{ Compared between } & \multirow{2}{*}{$\begin{array}{r}\mathrm{t}=2.032 \\
(\alpha=0.05)\end{array}$} \\
\hline & Groups & Mean & \\
\hline $\mathrm{L}-\mathrm{R}+0.25$ & Left*: Right** & $8.6: 8.1$ & $t=0.609 *$ \\
\hline$\Rightarrow \quad 0.5$ & Left : Right & $5.2: 4.1$ & $\mathrm{t}=1.127 *$ \\
\hline 1.0 & Left Right & $1.9: 1.8$ & $t=0.084 *$ \\
\hline$L+R-0.25$ & Left : Right & $8.7: 8.0$ & $\mathrm{t}=1.152^{*}$ \\
\hline 0.5 & Left : Right & $3.3: 4.4$ & $t=1.152^{*}$ \\
\hline 1.0 & Left Right & $1.8: 2.0$ & $\mathrm{t}=0.088 *$ \\
\hline
\end{tabular}

* Left foot in front of Right foot

** Right foot in front of Left foot

* not significant

*** significant

ている。（2）㩆現例の大部分の例では一峰性であるが，

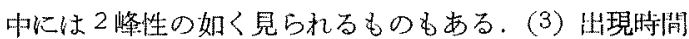
は第9表の醇りである。平均值でみるる $0,25 \mathrm{~mA}$ 刺战の 特 0.81 秒． $0.5 \mathrm{~mA}$ では0.65秒．1.0mAでは0.56秒であ る. (4) 加速度量は $0.033 \mathrm{~g}$ 程度であることがかかる。

V GAR 上の榐位と“振れ”

i） GAR 上の硔位を求めるには長周期性動摇波につ いて，0.5 秒閏隔点上で零線から推定基線までの距離を 測定した.すなわち20点において测定した距離の平诗 值 (20例の) を以つて interval diagram 作製した (第9 図の $1\llcorner 2)$.

右足前あるいは左足前の Mann 氏姿勢，開眼時の

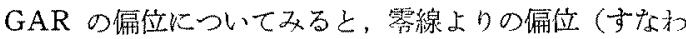
ち頭部の左右への傾き) は殆んどない，しかし閉眼後 5

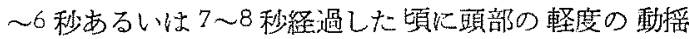
が出現する傾向がある。しかしそれらはいずれか一力 (左側又は右側に) に特に偏与る傾向は見られない，乙 してその後は安定して GAR 上の偏位当少くなる（第 9 図の1, 2 参照，以下同様).

$0.25 \mathrm{~mA}$ 通霹時には interval diagram に見る通り， 明らかに陽極側に偏位することが知られる。そしてい〜 1.5 秒の間に 1 つ大きい偏位があり，やや回復しつつ 5 6〜7 秒問に再び動摇偏位する傾向がある. 右足前の 場合之左足前の場合，それぞ机比較的良く似た diagram を示している

$0.5 \mathrm{~mA}$ 通電時には2〜3秒間に大きい偏位，続いて 5 
第9 表 Onset Time of Initial Wave on GAR of Clinically Healthy Subjects

\begin{tabular}{|c|c|c|c|c|c|c|c|c|c|c|c|c|c|}
\hline \multirow[b]{3}{*}{ No. } & \multirow{3}{*}{$\begin{array}{l}\text { Posture } \\
\text { Polarity } \\
\text { Intensity }\end{array}$} & \multicolumn{6}{|c|}{ Lelt loot-Right } & \multicolumn{6}{|c|}{ Right foot-Lelt } \\
\hline & & \multicolumn{3}{|c|}{$\mathrm{L}+\mathrm{R}-$} & \multicolumn{3}{|c|}{$\mathrm{L}-\mathrm{R}+$} & \multicolumn{3}{|c|}{$L+R-$} & \multicolumn{3}{|c|}{$L-R+$} \\
\hline & & $\begin{array}{l}\mathrm{ma} \\
0.25\end{array}$ & $\underset{0.5}{\mathrm{ma}}$ & $\begin{array}{c}\mathrm{ma}_{1} \\
1.0\end{array}$ & $\begin{array}{c}\mathrm{ma} \\
0.25\end{array}$ & $\begin{array}{c}\mathrm{ma} \\
0.5\end{array}$ & $\begin{array}{c}\mathrm{ma} \\
1.0\end{array}$ & $\mathrm{ma}_{0.25}$ & $\mathrm{ma}_{0.5}$ & $\begin{array}{c}\mathrm{ma} \\
1.0\end{array}$ & $\operatorname{ma}_{0.25}$ & $\begin{array}{c}\mathrm{ma} \\
0.5\end{array}$ & $\begin{array}{c}\mathrm{ma} \\
1.0\end{array}$ \\
\hline 1 , & Y. S. & $\begin{array}{c}\sec \\
0.8\end{array}$ & 0.7 & 0.5 & 0.7 & 0.5 & 0.5 & 0.8 & 0.8 & 0.8 & 0.7 & 0.6 & 0,5 \\
\hline 2. & K. T. & - & 0.4 & 0.5 & 0.8 & 0.5 & 0.6 & - & 0.6 & 0.5 & 0.8 & 0.3 & 0.4 \\
\hline 3. & M. I & 0.7 & 0.6 & 0.5 & 0.8 & 0.6 & 0.6 & - & 0.6 & 0.5 & - & 0.7 & 0.4 \\
\hline 4. & N. A. & - & 0.7 & 0.6 & 0.8 & 0.6 & 0.5 & - & 0.6 & 0.5 & 0.7 & 0.8 & 0.6 \\
\hline 5. & N. I . & 0.6 & 0.5 & 0.4 & 0.8 & 0.7 & 0.6 & - & 0.5 & 0.4 & 0.6 & 0.6 & 0.5 \\
\hline 6. & I. $\mathrm{T}$. & 0.7 & 0.7 & 0.7 & 0.5 & 0.7 & 0.7 & 0.8 & 0.4 & 0.4 & 0.9 & 0.8 & 0.6 \\
\hline 7. & M. K. & 1.5 & 1.3 & 0.9 & 1.6 & 1.0 & 0.8 & 0.8 & 0.8 & 0.8 & 0.8 & 0.6 & 0.4 \\
\hline 8. & M. M. & 1.1 & 0.6 & 0.6 & 1.0 & 0.8 & 0.7 & 0.9 & 0.8 & 0.6 & 1.0 & 0.8 & 0.6 \\
\hline 9. & M. N. & 0.6 & 0.6 & 0.5 & 0.6 & 0.5 & 0.5 & 0.7 & 0.6 & 0.5 & 0.6 & 0.6 & 0.4 \\
\hline 10. & M. O. & - & 0.6 & 0.5 & 一 & 0.7 & 0.7 & 0.6 & 0.6 & 0.6 & - & 0.8 & 0.8 \\
\hline & ean & 0.85 & 0.67 & 0.57 & 0.84 & 0.66 & 0.62 & 0.77 & 0.63 & 0.53 & 0.76 & 0.66 & 0.52 \\
\hline
\end{tabular}

第9图 GAR一頭部の偏位一

偏位の平均攧の interval diagram

1. 左足前 (Mann 勢)

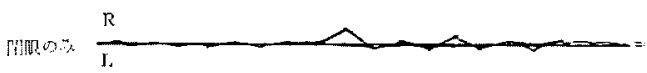

$0.25 \mathrm{mit}$
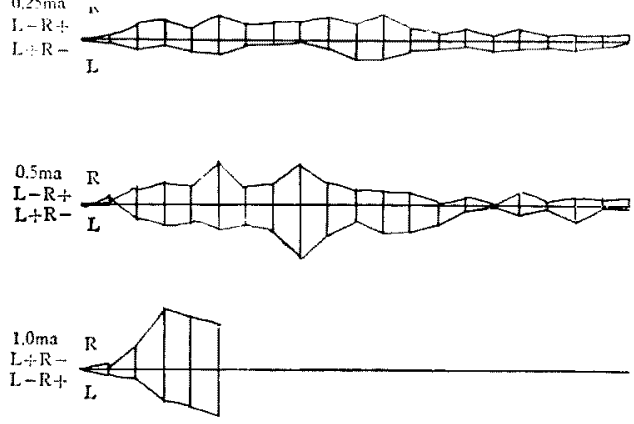

2. 右足前 (Mann 装等)
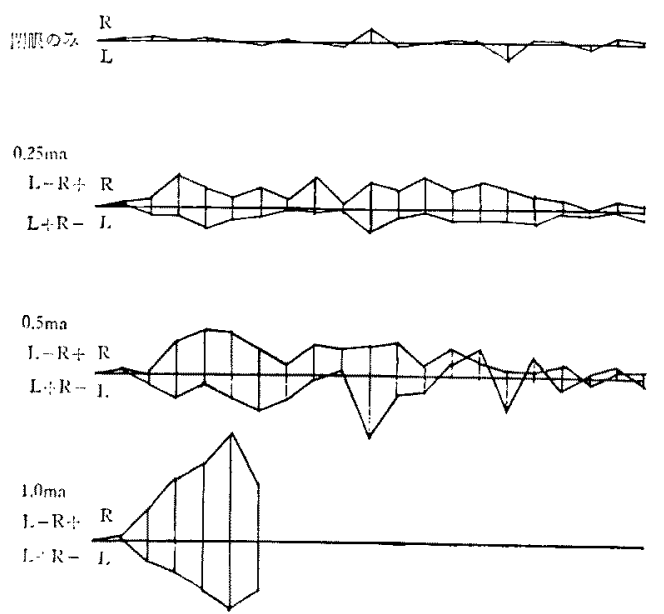

第 10 表 Acceleration of Head Movement induced by GAR-Test in Mann's posture

I. Right foot in front of Left

\begin{tabular}{c|c}
\hline & $\mathrm{g}$ \\
\hline Eyes closed only & $0.019 \pm 0.002$ \\
$0.25 \mathrm{ma} \mathrm{L}-\mathrm{R}+$ & $0.031 \pm 0.005$ \\
" ma L $\mathrm{ma}-$ & $0.029 \pm 0.006$ \\
$0.5 \mathrm{ma} L-\mathrm{R}+$ & $0.058 \pm 0.013$ \\
" ma L+R- & $0.070 \pm 0.008$ \\
$1.0 \mathrm{ma} \mathrm{L}-\mathrm{R}+$ & $0.115 \pm 0.054$ \\
" ma L $+\mathrm{R}-$ & $0.103 \pm 0.054$
\end{tabular}

II. Left foot in front of Right

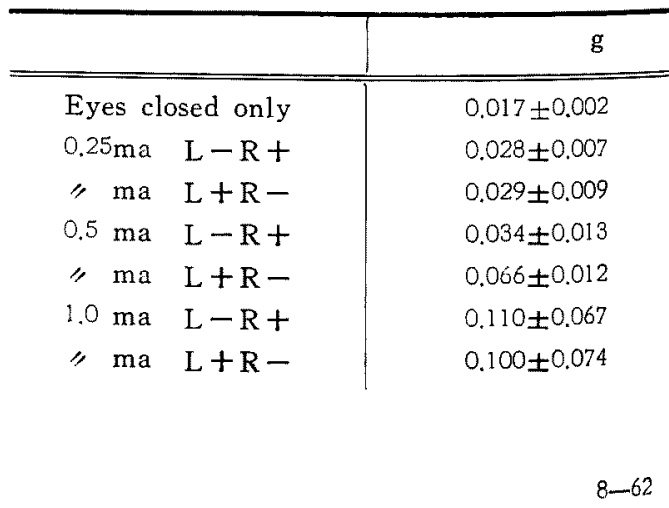




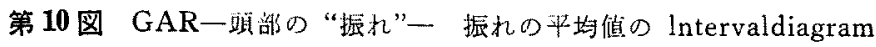

1. 左足婄

MU.

$0.25 \mathrm{ma}$

$\mathrm{L}-\mathrm{N}+\mathrm{i}$

0.25 ma

$\mathrm{L}+\mathrm{R}-$

$0.5 \mathrm{ma}$

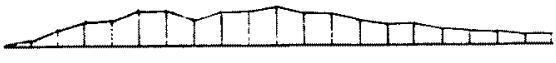

$0.5 \mathrm{ma}$

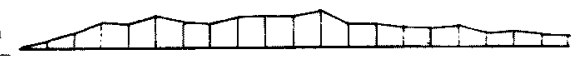

$\lim _{\mathrm{min}}$

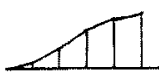

t)

$\mathrm{L}+\mathrm{R}$ -

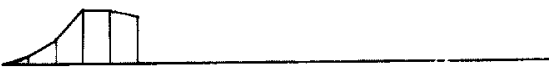

秒前後にさらに大きい偏位の傾向が知られる。転倒時間 の成續よりみて，この時間頻に転倒するものが多い。 の時期に転倒しなかつたものは，左・右に偏位しつつ躇 過して次第に安定してくる。

$1,0 \mathrm{~mA}$ 通電時には刺戱負荷 0.5 秒目頃より頭部（身 体）は急速に陽極側入傾斜偏位して 2.5 3.0 秒程度で䎐 倒与る、転倒直前あるい、転倒時の偏位が減じ，佘線に 近づくよに見えるか゚，これは足（下半身）が転倒側に 出る (stone から降りて) ため，相対的に頭部（上半身） が垂直位（举線位）に近くなるためであるら。

ii）“振れ”（頍部動摇の加速度）

前述の如く，通電に上る頭部傾斜で确位が起つている が傾斜しつつ䫒部（身体）は動摇する。この動摇の様熊 を頭部の振れとして観察する。この振れは GAR上， “侲位した基線”を姓定してその点あるいは線（傾いた 姿勢・位置で）より振れを目盛上に読及とり記録した。 数值は全て絶効值として技つた，0.5 秒間隔の平均値

\section{2 在足部}

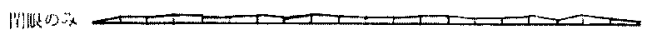

0.251141

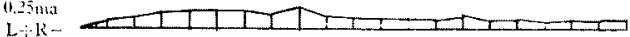

o) $5 \mathrm{ma}$
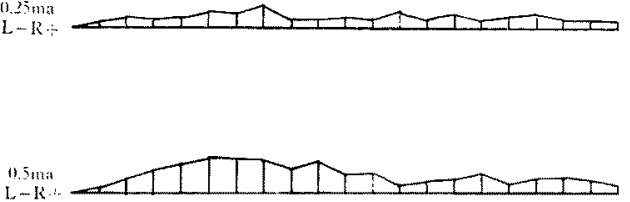

4)

L. $+\mathrm{R}$

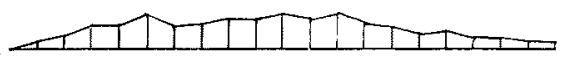

$1.9 \mathrm{ma}$

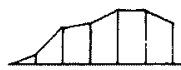

2,0 man

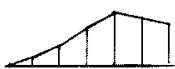

（20例）を表および interval diagram として表現する （第10表，第 10 图の 1，2）.

閍眼時には頭部の“振れ”に，さして变動はなく，僅 か、 0.019 0.017g 程度の加速度量を持つ.

$0.25 \mathrm{~mA}$ 通電時には2〜4秒経過特に振れがやや大き くなる，疤位にやや遅れて振れが大きくなる傾向が見ら れる、全経過の振れの平均值は約 $0.03 \mathrm{~g}$ である。偏位 の interval diagram とほほ同様に6 秒前後までは振子 は比較的大きいが，次第に振れ当小さくなる。

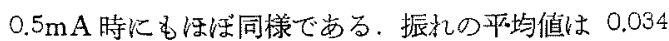
$\sim 0.070 \mathrm{~g}$ (平均 $0.056 \mathrm{~g}$ ) の加速度舅を有する. $1.0 \mathrm{~mA}$ 通 羿時には振机は急速に大さくなり，增大した偏位ととも に益々頭部動摇，身体動摇が激しいことが推知される。

2.5 秒 3 3 秒で転倒. 全経過の振れの平均值は $0.1 \sim 0.12 \mathrm{~g}$

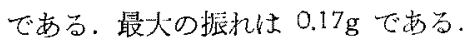

V 副作用について

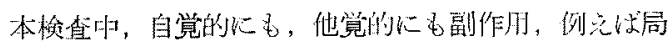




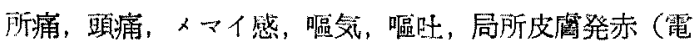
極貼布部)，けいれんなどの出現に注意し，あ机ば直ち に記入した，その結果，副作用は殆んどない，僅か2 例 が $1.0 \mathrm{~mA}$ 通電時に局所痛を訴えたのみである。他觉的 に熟められた局所皮磨発赤 (軽度) は約 40\%にあるが， 自賞的には局所になんらの異常感も訴えていない。この 発赤恰盉後間もなく消禎する。

VI い加る Galvanogram (関谷) について 第11 图の如く, Galvanogram 表現のための graphic scale を作整した。すなかち中央の目盛線は時間鿰で

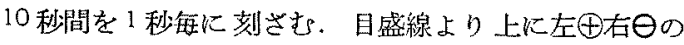
時に得られる GAR を記入する。目盛楾より下は逆の 㲠極々性の㭙，すなわち左 る、これによつて各 GAR での波形と転倒方向が目盛 線の方へむいており，さらに目盛線老はさんで相対して

第 11 図 Graphic scale for Galvanogram

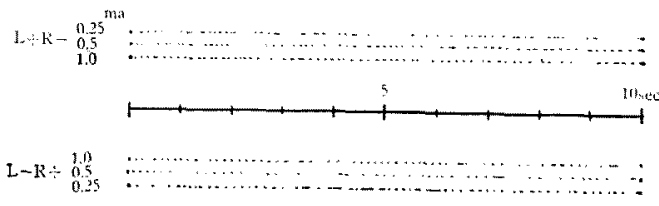

第 12 图 Galvanogram

No. CHS -1

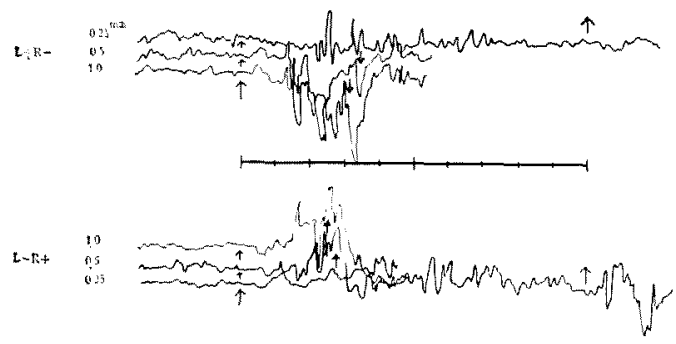

第13 図 Galvanogram

No. CHS -5

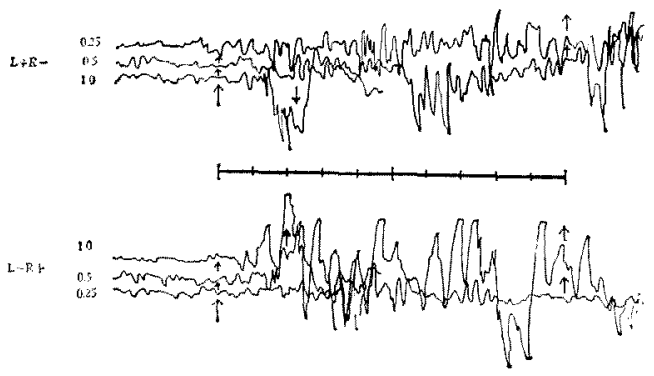

いることになる，左への転倒状態，右への転倒状態を鏡 像のよりに刘比させることができる，そして $0.25 \mathrm{~mA}$ ， $0.5 \mathrm{~mA}, 1.0 \mathrm{~mA}$ 各刺軲值で得た GAR pattern 孝をれぞ れに相当する所へ転写記入する（第 12 図，第 13 国).

このように質的に表示するとともに刺战電流但の各段 階每に記入，対比させることによつて量的に反応を示現 することができないだろらかと考えたのである。

これらをさらに簡略化して転倒時間だけを記入した simplified galvanogram を作る. 20 名の simplified

第 14 图 Simplified Galvanogram 一覧 (20 Healthy adults)

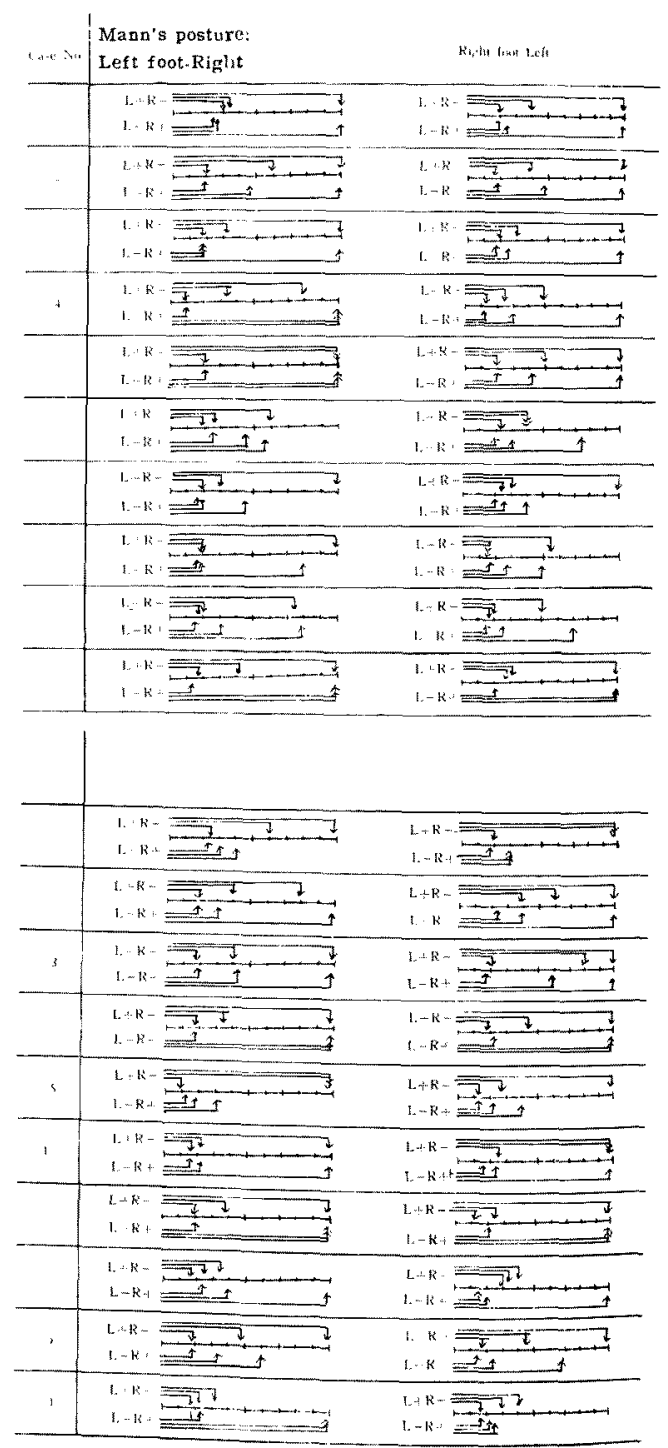


galvanogram を一覽表として揭载する（第14图）

$$
\text { 総 括 }
$$

前庭機能 検查法の内の Galvanic test の一変法とし

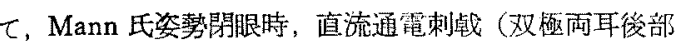
法)時の頭部動摇を加速度計を用いて記録钼察，解析与 る方法（GAR test）を健康成人 20 名代試名て次の諧結 果を得た。

1）Mann 氏姿勢閉眼時には䫓部の偏位および振れ

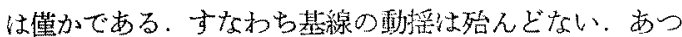
ても特に一方向へ偏寸ることは少い，振れの加速度量は $0.018 \pm 0.002 \mathrm{~g}$ である。

2) 双極再耳後通䉓刺战によつて，一般に頭部は最初 陰極側入向5小さい波（初発波と乎ぶ）が出現する。引 絸き陽極側入の傎斜がはじまり，肉眼的推察に上つてす 動摇・徧位が判るようになる。傾斜・動摇の後，復位 (弱刺㦸值の時)するものと，そのまま陣極側に転倒(強 刺㦸の時)するものがある。

3） $0.25 \mathrm{~mA}$ 通電時には軽度または中等度の頭部動摇 を誘発する、しかし転倒することは少い，約 $70 \%$ は 10 秒以上直立位を保持し得る．傾斜方向は陽極側入向亏。 哂倒時間（平均）㤌8.3秒である。振れの加速度量は $0.029 \pm 0.0067 \mathrm{~g}$ である。

4) $0.5 \mathrm{~mA}$ 通電時には中等度の䫓部動摇をさたし，陽 極側への傾斜偏位も大きくなる、転倒時間についてのバ ラツキは大きい，平均転倒時間住 3.3 秒〜 5.2 秒である。 振れの加速度量総平均は $0.057 \pm 0.0115 \mathrm{~g}$ である.

5) $1.0 \mathrm{~mA}$ 通電では頭部の動摇は大きく，急速に陽掼 側傾斜し，転倒する，平均転倒時間は1.8〜2.0秒であ る.

6) 転倒時間の平均值とそれらの信頼限界 (5\% の危: 除率で）は， $0.25 \mathrm{~mA}$ 通電時は $6.4 \leqq \mathrm{~m} \leqq 9.6$ 秒。 $0.5 \mathrm{~mA}$ の時炕は $2.8 \leqq \mathrm{~m} \leqq 5.4$ 秒， $1.0 \mathrm{~mA}$ の時は $1.5 \leqq \mathrm{~m} \leqq 2.5$ 秒 である。

7) 転倒時間の各種条件火上る差の有急性:

i）三種の電流値による差つ間に砝んど有萝が認か られる. 特に $0.25 \mathrm{~mA} と 1.0 \mathrm{~mA}$ との間の盖つ有意㥄心 著明である。

ii）極性桨換による差の有意性認訲られない、すな わち左右差は誋められない。

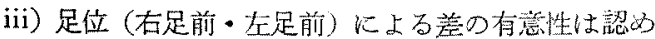
られない

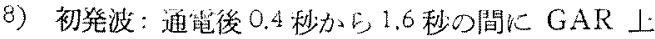
最初に発現する動摇波を呼称する．0.25 $\mathrm{mA}$ 時には半明
しない場合があるが，0.5 $\mathrm{mA} ， 1.0 \mathrm{~mA}$ では明らが見得

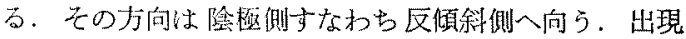
時間の平均は $0.25 \mathrm{~mA}$ で出る場合は 0.81 秒， $0.5 \mathrm{~mA}$ で は0.65秒． $1.0 \mathrm{~mA} て ゙ は 0.56$ 秒である。乙の加速度量は $0.033 \mathrm{~g}$ である。

9) GAR の倘位と“振れ”：偏位は Mann 姿攀閐眼

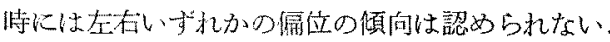

$0.25 \mathrm{~mA}, 0.5 \mathrm{~mA}, 1.0 \mathrm{~mA}$ ではそれぞれ陽極側に，電流

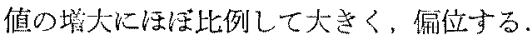

“振九”は電流值の墦大に比例して大きくなる。 その 硅㹂（總平均值としてみると）は閉眼時には $0.018 \mathrm{~g}$ ， $0.25 \mathrm{~mA}$ 通電特には $0.03 \mathrm{~g}, 0.5 \mathrm{~mA}$ 時には $0.056 \mathrm{~g}, 1.0 \mathrm{~mA}$ 時には $0.1 〜 0.12 \mathrm{~g}$ である。

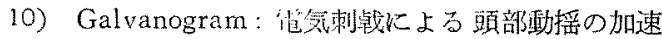
度記録图 (GAR) 劣 Calorigram 類似の scale 上に各 極性，各刺㦸電流值を考罾して，転写し前庭背䯙反射と しての頭部動摇の澡度を質的・量的に知る方法を試み た. 特にこの simplified Galvanogram によつて反応 の概略を知り得て有用である。

11) 副作用については，本法では特記すัべきものは ない.

12) 基本的波形の棈成々分

GAR によつて得られる頭部動摇の波形について以下 の上うに構成々分を分け，呼称する，文の各々について 現象経過順に述べる。

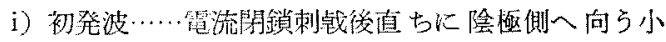

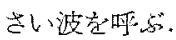

ii）傆斜・動摇波……次いで陽極側入向い傾斜動摇す る波.

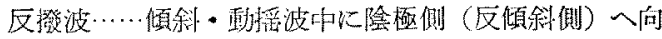
弓大き無㷊波。

iii) 乾倒波……枟倒時の動摇波.

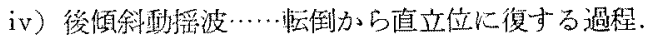

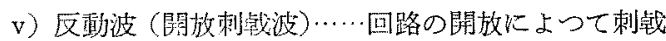
され，反刘僛へ向け，湤しく期摇することがあるが，て の際形成されるものである。以上の順を経て基線に展

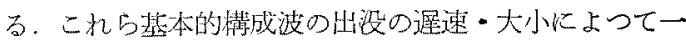
罗異つた波斑形作る。

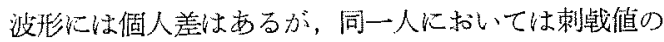
大小以よつて得られる各波形に類似が求められる。去し て刺㦸檤の增加にともなつて波形は水平方向に短縮圧迫 さ礼た形（丁度手風琴の伸維に似て）となり，上下に高 低の大きくなる傾问がある。 


\section{考按}

文献的挑項（主として Galvanic test の）電気刺䄀, 特に頭部通電によつてメマイ感，眼振などの誘発され ることについては Voltaが 1792 年に発表したのが最初 であるとい5 (Augustin 33))。ささらに1803 年に Ritter あるいは Augustin が夫心独自に䂧究・報告している。 1820 年には Purkinje が錐呠骨を分して電気刺战を加 えてメマイその他眼運動の発来寸るここを発表してい る. Hitzig (1871) が同様汇人の頭部に通電して腿振の 呿こることを認め，Breuer (1874) は弱電流を試獣の 頭部皮旊表面より通䉓して眼振の 発来する䠌実より，

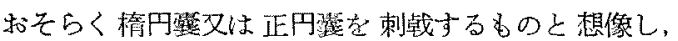
diffuse Reaktion と名付 5 t. 以整 Ewald \& Wollenberg (1911), Molinie (1922), Neumann (1907), Bárány (1907), Mackenzie (1917), Ruttin (1926)

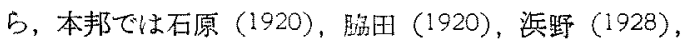
小田 (1929), 南 (1930), 小出 (1931), 奈良 (1934)

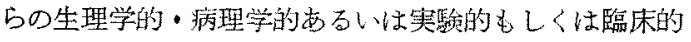
研究がある。

乙かし近時この方面での研究報告は比較的少く，他の

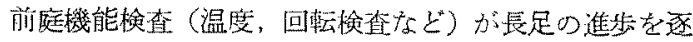
げて，それらが定性的のみならず定量的に检盗され，さ らに走れらの方法にある程度の基淮化がなされているの に反し，Galvanic test のみが看過されているよ5に見 克る。

Mackenzie 5)(1917)は8 年間に亘つて Galvanic test を実施研究してきた結果として報告し，本法をきわ的て 后い検査法であると强調した。すなるぢmore accu一 rate than the caloric or rotational test" であり, "the most sensitive and the easiest to control, of the labyrinthine tests" であり, "Unilateral test" 等々であり,さらに “Galvanic test is the only one possesed for testing the function of the eighth nerve in cases of neuritis or in cases of secondary degeneration following destruction of the inner ear" $\tau$ あると多数の長所を列举して本法の有用性を大い:强調 したにもかかかわらず, Peitersen \& Zilstorff-Pedersen (1963) 子記述する速り，i）前庭系のどこに通笪制战の 標的があるか， ii）一定した刺軲状態が得ら机るかとい、 うことや，iii）やや一定值を求め難いこと，又iv） 極設置法についてはつきりした一致意見がなかったこる

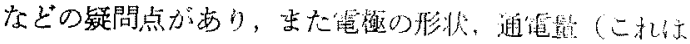

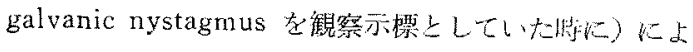

つては局所痛がかなり強く，一般通念としてわれわれが 持つている電気に対する琹怖感と相侯つて敬袁されたり もした，そして教科書，あるいは諸種参考害中，前庭機 能険查法とい党ば種々記载して来て，必ず温度検查，回 転検查，電気検查と列記されるに拘らず，電気検查の 利用頻度红誠任低い上うに見觉る。

近年，臨床上 Galvanic test に関して比較的系統的 に検查，呼究報告されているものは数紙を数劣るに過き ない. Dix, Hallpike \& Spencer-Harrison 12) (1949) 俚当㭙注目され始的た抗結核剤 SM が第8 脳神経系を 選択的に执かすことより，SM 投与例12名について, Caloric test, optokinetic test ならびに galvanic test を実施した，特に galvanic testについては対照検查 (control observation) 12 名の正常人について行つて いる，すな放ち双極法 (bipolar stimulation)（乳安部 之胸骨唡上に）で接足直立閉眼位で，陽極側への動摇発 現（swaying）を当つて区応陽性とし，その時の䉓流值 を記録している，無論，極性を变光て夫ょに行う，その 成䅡を一臨表として出しているが，それによると1個人 については，電流值に特に左右差はない上らである。さ らに Dix らは陽性反応時の電流值平均は $0.3 \mathrm{ma}$ 加 1.9ma であると述べている。

Ingelstedt \& Walander ${ }^{13)}$ (1949) \& SM 中毒患者 20 名に 対して双極両耳法あるいは汉極単耳法 (handear）で険查し報告しているが，その記載の中で通常（正 常上解釈)では 2 3 $\mathrm{ma}$ で眼振が陰極側へ向つて出る と述べている，その他增田 (1960), 福田他 (1962), Peitersen \& Zilstorff-Pedersen (1963) などを見る.

従来, Galvanic test の钼察示標は電気刺㦸で “謡発 される眼振”を以つてする場合が多い上ら炕見光る。し かし少数の人々が前庭替的造反射を示標として検查を行つ ている。すすなが, Bàràny (1907) と Quix (1926) \%7 は通電によつて past pointing test に偏示が現われるこ 々を； Fischer \& Wodak (1924) は電気刺钱で arm-

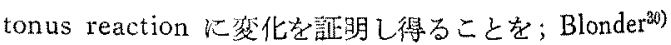
（1937）估 “balance board” の上K通常立位でいる时， 通笔して galvanic falling (この場合 platform の陽梗 側への傎斜)の扣こることを示橴として顧察；Dix

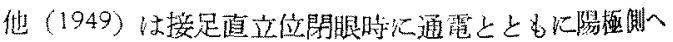
の動摇（Swaying）のおこることを示標とし；教室の曙

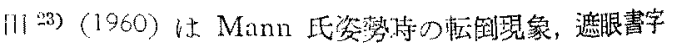

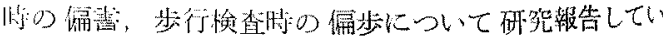
る。㶢の他 Peitersen \& Zilstorff-Pedersen (1963) 
步行㭘筧特の偏出についての報告等をしている。 前庭反応誘発䉓流倠について

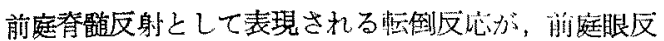
射として誘発される nystagmus より弱い前庭刺茂（こ の場合電疑刺戟）によつて惹起されるこよはよく知られ ている事実である．実際，人についての報告で Jongkees 15) (1953) 惼倚誘発には 2〜3ma, 眼振誘発には 3 ４ma と記載し，Fischer ${ }^{1)}$ (1956) は両極法で転倒も しくは䎐倒傾向は 1〜1.5ma で患者火不快感を与えるこ となしに誘発し得る一方，眼振觀察には 2〜 $5 \mathrm{ma}$ を要 すると述べ，また Peitersen \& Zilstorff-Pedersen 28) (1963) は体の動摇は 0.2 0.8 ma（平均 0.5ma）で扎こ るが，眼振誘発には 3.0 5.0ma (平均 $4.0 \mathrm{ma}$ ) を要し， から強いメマイ感，身体不安定を伴うと報告している。 これをみると電気性 転刨反応は電気眼振の大略 $1 / 2$ $1 / 8$ 程度の弱、電気で起り得らことが知られる。

著者の成績では双極両耳後法（同大の小川板電極接 着)で Mann 氏姿勢閉眼時に転倒反応を誘発する麗流 值は $0.25 \mathrm{~mA} \sim 1.0 \mathrm{~mA}$ である.

すなから，著者は転制するに要する電流闘值を直接求 めているのではなく，規定電流に対する転倒反広の有 無，様態記録観察しているのであるが，0.25mA でも 約 30\%が転倒反応を示し，さらに $1.0 \mathrm{~mA}$ では全例転倒 反応が括こつていることより推定しらる。

電標ならびに刺战装犆について:

電極の形状ならびにその設置部位はそれぞれの研究者 によつて，種々その形，大きさ，部位，固定法などが考 案されているるのである。ここには主として栾休上用い られて来た電極ならびにそれらの部位について文献的に 考察し言己述する。

刺战置 (平流電気発生㳖置)について子同様のこと が言える。

電気検查を迷路反応の臨床検查法として始めて用いた Neumann (Fischer 1) とよる) の雪極の形状とそれら の設祭部位は未詳である。しかし Mackenzieら)(1917) は a small ball electrode（值径 1/4 inch または々机

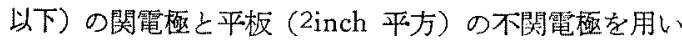
ての単極単耳法を用いていたようである。装置について は適当な電気刺㦸器 (suitable electrical apparatus) が必要であり，それは接触がよく正確な milliamperemeter 有し，極性変煥 SW のあるるのと述へててい b.

奈良 ${ }^{9}$ (1934) は耳奥科にて日常治療に 使用していた
“Kataphor Apparat”（特殊の琣流発生㙨てミリアンツ アィーター、微絊調節用抵抗器などを組合せたもの, い 源は $100 \mathrm{~V}$ ○灯用線より）を用い，関電極に直径 $1 \mathrm{~cm}$ 弱の球状の女の，不関電極に平板 $(10 \times 4 \mathrm{~cm})$ で, 単極 単耳法とし，耳珠に関霓極を，不閔電極は反対側前膊の 屈側部を巽んでいる。

1947 年, Glorig \& Fowler ${ }^{36)}$ は双極両耳法によつ

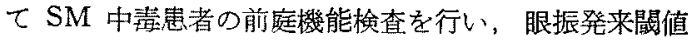
を求めている.

1949 年, Dix, Hallpike \& Spencer Harrisonは pad 老用いて雨極雨耳法 (兩乳突部) あるいは雨極単耳 法（乳突部と胸骨柄部とに）でもつて通電検査してい る、装㩆については不詳である。

Ingelstedt \& Walander (1949) 13) b双極两耳法市 るいは双極単耳法 (hand-ear application)によつてい る。刺㦸䔩置については記載されていない。

Richter \& Pfaltz ${ }^{37}$ ) (1959) は双極両耳法 (耳後部) または単独法で眼振を観察するが，これを光電的 ENG 志応用して記録している。福田ら (1962) 《值径約 $2 \mathrm{~cm}$ の円板電極 2 ב（同大）丟用い，双極雨耳法で行つてい， る. 刺战装歶は市販のイトー式マスキューレーターD 型 (平流刺㦸発生装置) を使用している。

Peitersen b㥀径 $3 \mathrm{~cm}$ の円形電極を用いて種々の 電極設置の組合孔を以つて検查している。

以上要与るに電極の設置法としてい，

1) 単極単耳法

2) 単極雨耳法

3) 双複単耳法

4) 双極雨耳法

の組合せがあり，さらに前頭胸部法 (Front-mammary) (Hennebert) がある。しかし最も弱いあるいは小さい 通電量で反応が得られること，副作用が最も少いことな とから，双極雨耳法が一般に推奖さ机ている

著者は別途に行つた単極一耳後部通電法によつて得ら れる GAR の成績上双極兩耳後法における GAR の成 績が互い全く近似する実験萧実（第 15 図）之，本検 查上左右の極性変换が容易火行兄る利点と，さ5に局所 の疼痛が少いことなどより，本研究では双極雨耳後法 によつて行うことにしたのである，直流電気刺战装置に ついは前述の如く本研究の目的のため教室の野中が考 案作成したものを用いた。

加速度計（非接着抵抗線加速度変換器）ならびに加速 度記録㘣に関して： 


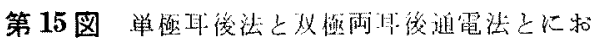

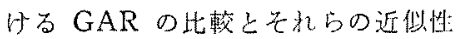

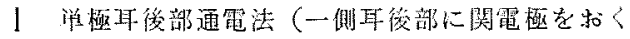

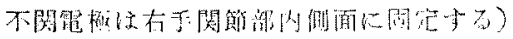
波䉓

A.

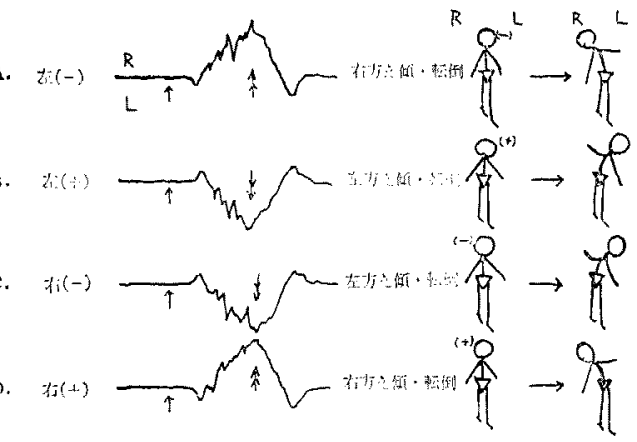

II 双極両耳後部通電沙（両耳镍部にそれでれ 同大の電極を貼付する)

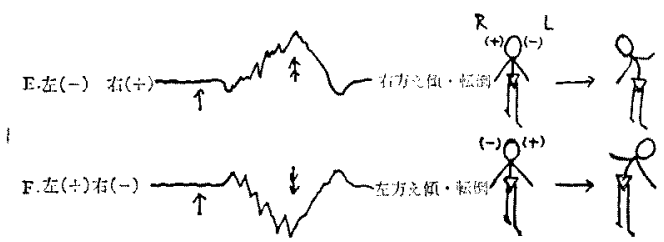

要するに, 波形 $\mathrm{E}$ (左(一) 右 (十) 蚾形 $\mathrm{A}($ 左 (一) ) と波形D $($ 右 $(+))$ とて, 波形 $\mathrm{F}($ 比 $(+)$

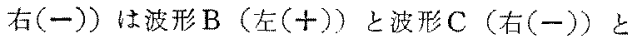
に，无れをれ全く良く近似するこ上が判古。

歪計 (strain gauge) (以下 SG と略記) 㜔線の伸 縮にともなつてその電気抵抗が極めて放細であるが確实 に增減寸ると言ら原理を Lordkelvin 加発見し, Baldwin が央用化したものだが現在工業方面において各種 の測定に利用され，その応用籍国は誠に広籍田である。

ストレイン・ゲージは機能・形式より二大別できる。

1) 接着抵抗線型企計と 2) 非接着抵抗線型全計である. 後者の非接着抵抗楾型計器恃紙ゲージャ゙ークライトな どの接着型ストレイン・ゲージと異り, 被測定物に㙋り

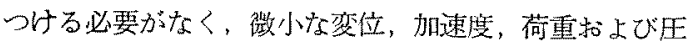
力などの物理量を電気量に变換することができる。共和 電業では特に加速度を測定するためのA 㤠加速度变换 器 (linear accelerometer) を開発した。これは極めて小 型軽量でしかも固有振動数もか广り高い。これら動的疋 の測定・記録には糸換出力は程測定器を通して增幅して オシログラフに現象を記録して行くことがでさるるので
ある。

この種計器の工学的方面におけりる灾用分野は極めて厸 く，以前より用いられていたが，医学研究の領域にも近 华学入医用され始めた。

Jongkees \& Groen (1952) 2) は physical-mechanical method 支駆使して人間の前庭器官の機能解明に務 わ，特に前庭器宫の活動性を詳しく知㕣ために加速度の 穖序を追求する一つの手段として感応コイルを庙した 一種の加速度計（可動線輪中の induction current の 要化をピック・アップしている）を人の頭部につけ，歩 行中の各種加速度の测定を行い，特に正常人ならびに患 者について步行時の頭部動摇の加速度記録図を観察して 著差のあること定認め，人の歩行運動時の迷路刺战の様 態圭考察している。著者の知る限りでは本邦蝴る SG の医学方面の応朋は菅野 (1953) が脈生計として，

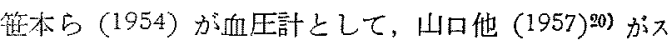
トレイン・ゲージによる生体微小王变化の測定法につい て報告し，SG を用いる方式には電子回路に拈ける機㖑 的国難性があるが，こ机索党服す扎ば，生体微小王变化 の郡録・測定に定量的に応用し得ると述べている，そし て山口らは指尖プレチスモグラフに本法を広明している のが見られる

北原 (1959)21) は前庭迷路の生理学的領域に，本邦で

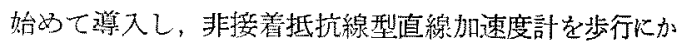
ぎらず，種々の静的動的姿勢の頭部動摇の記録に応用し ている。内海他 ${ }^{39}$ (1961) は「内耳性筋反応関する研 究」の中にて，動物に直線運動を負荷し，その移動時の 刺戥の强さ，叔よびその㭙間的変化の経過を記録する方 法として SG 在死用して加速度計を試作応用して“满 足すべき成果”を得ている。

以後，加速度計㐫用して身体動摇を観察したもの は，宇里 26) (1963) が平衡機能の年令的恋遷に関する研 究に用いまた Mann test 時における頭部動摇の左在 成分の比較检討についての考察を行つている。

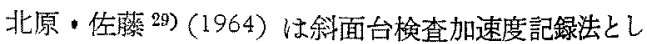

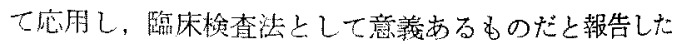
ものがあるのみである。

われわれる数年来，加速度記録图法を諧種前庭機能检

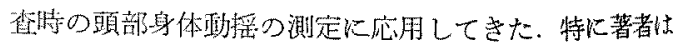
管気検筌 (Galvanic test) 時の頭部動摇を加速度記録

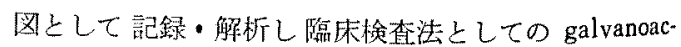
celeroregistrogram (GAR) を試み，これの前庭譏能 検盂法としての有意滰泩を䃘究してきた。 
Galvanic test に関して，その钼察点 (示標) を他覚 们客観的飞記録して報告したものは極めて少いすすなわ ら観察示標を Galvanic nystagmus に求めているもの は最近著しい発達普及した ENG 記録法によつても不 満足な結果を得ているからであるち（電泒の雑音が強烈 に入ること，通常の ENG では電氮的眼振はあまりに も振幅が小心ことなど). そこで, Richter \& Pfaltz (1959) は光電的 ENG を応用観察している報告がある。

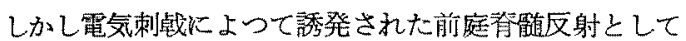
の頭部動摇を“示標”として観察したものにはその他覚 的客観的記録を行つた報告は誠に少い。

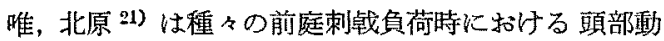
摇の加速度計沉上る破究を行い，その中で接足直立閉眼 位の被検者に $0.5 \mathrm{~mA} 20$ 秒間, 双極雨耳法で通電して 誘発した頭部動摇を記録している報告がみられるのみで ある、それによれば，開眼時には通電による頭部動摇の 発現は見られないか，僅か心推知せられる程度である か゚，閉眼時には頭部動摇が著明に誘発されることが知ら れ，それも陽極側の万向に傾䣄・動摇することが記録さ れている。そしてこの加速度記録四法は前庭身体反射の 表示として有意義であると絬論している。

著者らも前述の通り，この加速度計を用いての頭部動 摇の記録によつてほほ满足すべさ成縝を得ている。そし て関係計器の小型化によつて日常臨床検查, 特に諸前庭 脊檤反射の記録分析に頻用されるよらになるであるら。

通電時頭部動摇の力向性について

著者の実験では，通電中頭部の動摇，傾斜あるいは身 体の転倒の方向は，陽極側入向い，電流を切ると逆に㓌 極側入向つて動摇（時に転倒）する。この方向性につい て北原の成績をも参昭しつつ考察を加党ると; 接足直立 閉眼位で，左耳に冷刺戟を与えた時の頭部動摇の方向は 同側に向つていること(すなかち眼振緩俆相の方向). 一方，同様の姿勢で左十右一の電気刺战を負荷した時， 頭部動摇は左方へ向つていること，すなわち陽極㑡に向 5.

これらのことより， Fischer \& Wodak (1924)が Arm-tonus reaction を勧察示摽として研究した結論と して陽極刺战は冷刺战時の反応態度に; 㓌極刺韩は温刺 战時のそれに相当すると述べている成績に一致する。

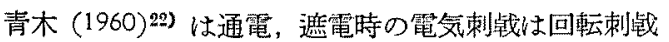
と甚だ良く似た成績を示すと述べ，実験動物（家鴧）は 通電之同時に陽極側入著しく偏倚し，通笔中この偏倚姿 勢をとり，陰極側に向ら頭振を盛えに発来すると言う。
さらK石川 (1959) 34 ) は家鬼の中耳腔筲胞を開放L, 正

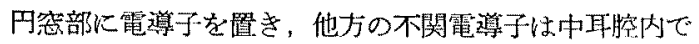
外側縁部に置き，直流通電した場合の体位变化定 EMG を用いて研究しているが; 院極通雪刺战の場合, 顕著な ことは頭部の偏位で，刺㦸の反刘側に傾斜，やや後屈す る、前肢は刺皒側で軽度に伸展，対側で屈曲。身是幹は刺 㦸側を凸面として軽度に絽曲する。このよ5な休位变化 は通電中持続している，所が一方，陽極刺战では；頭部

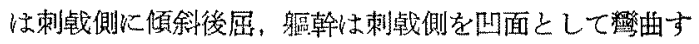
る.すなわち院極刺战の場合とすべて逆の反応であると 述べ，さらに筋電図学的に與味ある所見を得ている。す なわら㓌極刺战により, 刺㦸対側の深風項筋, 仙棘筋, 前肢の屈筋お口よび刺战側の前肢伸筋において筋放電頻度

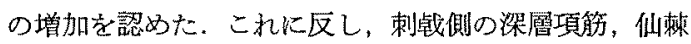
筋，前肢筋和よび刺㦸対側の前肢伸筋は筋放電頻度の減 少を証明し，他力，陽極刺㦸の場合，㓌極刺㦸の成績と 全く逆の筋反応を証明しており，迷路通電刺㦸の効果上 して，それぞれの支配下にある骨格筋の放電䫍度は㓌極 通雷で增加，陽極通電で減少をさたすすのであるらと述 ベている.

本実験に持ける一定方向八の動摇・偏倚，転倒現象を 説明するに，陰極通電刺㦸は寀路性筋䇣張を昂め，これ に反して陰極通電刺战㴹路性朌繁張を低下せしめてい 名事夷 (石川 ${ }^{34)}$ ) 巳5に通電中迷路性筋緊張は持続的

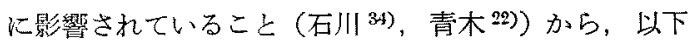
の加く解䣋される。すなわち，通電により，動摇・偏倚 をきたすのは，弱電流通電刺㦸が加つた時，旡極側では

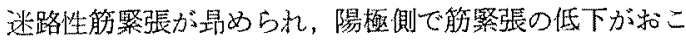
る.これによつて全身筋群の迷路性筋緊張の変調, 特に 左右の美の現れとなり, 頭部（身体）の動摇・偏倚をさ たし，さらに進んでは迷路性筇㗨㖘の著しい失調によつ 七転倒現象を惹起するものと考える。

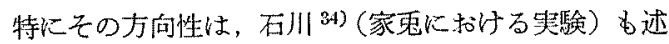
ベる如く，迷路性筋反応は深層項筋，仙栜筇，前肢筋に 対して交父側性に，前伸肢筋は同側性に主として出現し ていると述べているが，これらの筋肉，就中仙噧筋は人 体にあつても起立姿勢を維持子る抗重力筋としてその㗢 きななす役割は大なるるのがあると言う。

これらの事実より，㓌栖通電の対側（陽極側）の骨格 筋において，㬳緊張が高まり，その結果，頭頸部・軀幹 が陽極側に向つて屈曲偏倚する現像が湛現されるものと

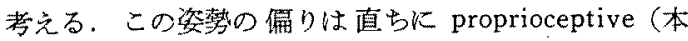
奏験の場合視性の調節は除かれているとして)，迷路な 


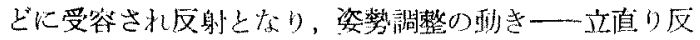

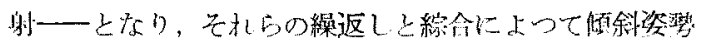
の中で反撰性の動摇波を括こず

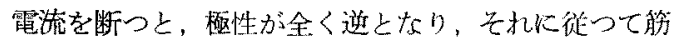

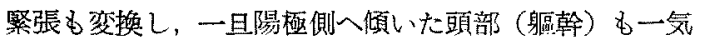

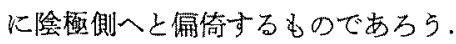

しかしこれらの機序はさらに複雑なるのであること は, 姿勢の調節にはこ机ら迷路, 視器, proprioceptive, exteroceptive のみならず，さらに二次的（又は一時的 にも）に高位の中种の影響を受けているからである。

\section{結論}

Galvanic test を患者への負担を少くし，加つ簡単 で，さらに定性的・定量的に奏施するための試駼研究责 目的とした，そのために，Mann 検查時姿茄・閉眼位 の通電時，転倒現象を示標とし，規定した 3 種の㐷電気 刺战を用いる。さらに加速度記録図法を応用して頭部湢 摇・傾斜・転倒現等を他覚的咨観的に記録・分析した， 電極は值惩 $10 \mathrm{~mm}$ の円形銀板電極 2 口用い，双極雨 耳後法上した。

電気刺㦸時加速度記録図を Galvanoacceleroregistrogram (GAR) と呼称する.

偝康成人 20 名について本法を行い，以下の成績を得 た:

i）通電によつて先ず陰極側へ向ら小さい陲摇がおこ る(初発波と命名).

ii）陽極側への比較的文は全く著明な嗔斜，時に転倒 が起る。

iii） $0.25 \mathrm{~mA}$ では勘摇は少く, 初発波, 枟倒現象の出 現は少い、1.0mA ではそれらは殆んど必発する。

iv) 電流值の增加によつて現象の出現時間は短維し， 㨝位な上び“振孔”は大きくなる。

v）極性を玟えてb転倒時閒に有意の左在差を認めな i.

vi) 転倒時間の平均值は； $0.25 \mathrm{~mA}$ 刺㦸時， 8.3 秒. $0.5 \mathrm{~mA}$ 時， 4.4 秒，1.0 mA 時，1.9秒である.

vii) 初発波の出現時間は平均 1 秒以内である。

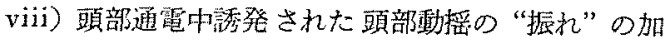
速度量は全程過の平均としてみると：Mann 氏等，閉 眼の双のとき， $0.018 \mathrm{~g}$; 同上， $0.25 \mathrm{~mA}$ 通電時， $0.03 \mathrm{~g}$; $0.5 \mathrm{~mA}$ の特, $0.056 \mathrm{~g}: 1.0 \mathrm{~mA}$ では 0.1〜0.12 であつた。

ix）副作用として特記すべき或唡はない。

x）いわゆる Galvanogram の表現法については今後、 踇床例の Galvanogram の結果との比較検討を行なう。
結語

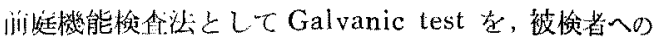
争担が少くから簡易で，さらに定性的・定量的に実施 与るための基準化を目的とする，そのために Mann 检 查時姿藝・開眼位の通䉓時，転倒現象を示標とし，規定

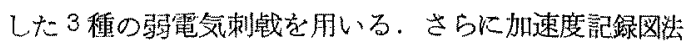
を応用して誘発される頭部動摇，傾斜，および身体の転 倒現舜を他賞的管観的に祀録・分析与万方法 (GAR test）学考案した，健康成人 20 名について本法を行い， 此較的一定した成績を得た。

\section{主要文献}

1) Fischer, $J_{\text {.: }}$ The Labyrinth. Grune \& Stratton Inc.(U.S.A.), 1956. 2) van Egmond, Groen \& Jong. kees: The Function of the Vestibular Organ. S. Karger A.G. (Basel)，1952. (内海真夫訳，医獭薬出频 1959). 3) 木谷若一：オシログラフの理諭上取报，

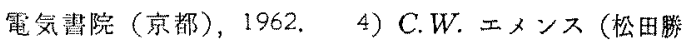

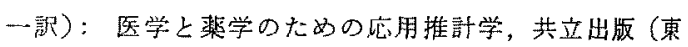
京), 1955. 5) G.W. Mackenzie: Galvanic Test of the Internal Ear. Layngocscope, 27: 200, 1917.

6) Huizinga, E.: De la réaction galvanique de láppareil vestibularre. Acta Otolaryng., 15: 451, 1931 . 7)南：電気刺戟による恥器障碍の実験的研笲，1， II, III, 耳臿臨，24(1)：1930 (小出上り)。 8) 小出 釥: 電気刺战後に発来する特発性眼振の末梢迷路説(南

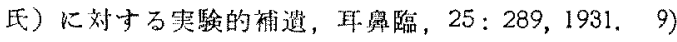

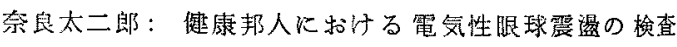

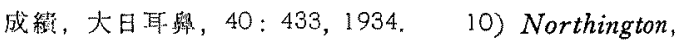
P. \&. Barrera, S.E.: The Galvanic Nystagmus Reaction in the Monkey. Am. J. Physiol., 120: 703, 1937. 11) Dohlman G.: On the mechanism of transformation into nystagmus on stimulation of the semicircular canals. Acta Otolaryng., 26: 425, 1938. 12) Dix et al: Some observation upon otological effects of streptomycin intoxication. Brain, $72: 241,1949.13)$ Ingelstedt \& Walander: The Effect of Streptomycin on the Galvanic reaction. Acta Otolarng., $37: 521,1949 . \quad$ 14) Dix \& Hallpike: The pathology, symptomatology and diagnosis of certain Common disorder of the vestibular system. Ann. Otol. (St. Louis), 61 : 987, 1952. 15) Jongkees: Die galvanische Prufung. Forts. H.N.O. Heilk., I : 128, 1953. 16) 上塚万寿男：電 


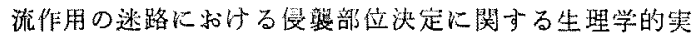

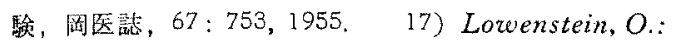

The effect of galvanic polarization on the impulse discharge from sense endings in the isolated labyrinth of the thorn-back ray. J. Physiol., 127: 104, 1955. 18) Johnson \& Brydon Smith: Differentiation of intracranial \& peripheral vestibular lesions. The Laryng. (St. Louis), $67: 669,1957$.

Hahn, R.: Beobachtung über Wichtigkeit und Klinische Wert Klinischer Vestibularis-reizung. Ann. Laring. ecc, $55: 214,1957$.

20) 山口，他 : ストレインダージによる生体微小生变化の测定法につい

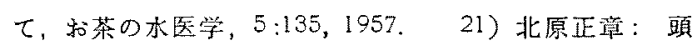

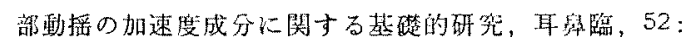

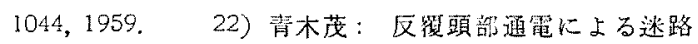

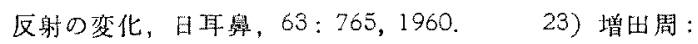
Galvanic Test の研究, 耳鼠監, 53: 1507, 1960. 24)

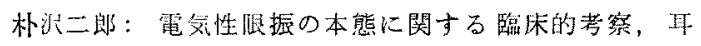

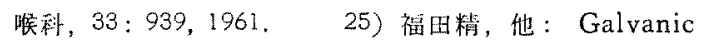
Test の一規潗，日耳與，65：279，1962。26）宇野良

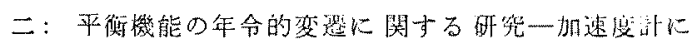

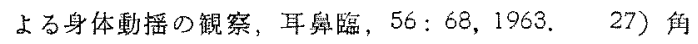

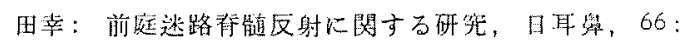
332, 1963, 28) Peitersen \& Zilstorff-Pedersen: Vestibulospinal Reflexes. III. Arch. Otolaryng., 77 :

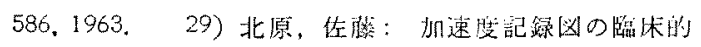
応用, 耳舞臨，57:57, 1964 30) Blonder: Galvanic Falling in Clinical Use. Arch. Neurol \& Psy-

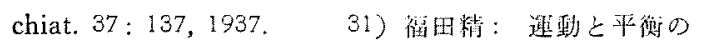

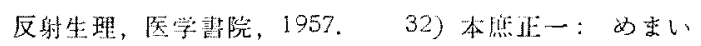

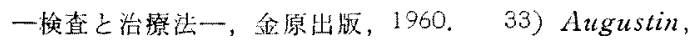
F.L.: Versuch einer Vollstandigen systematischen
Geschichte der galvanischen Electricität und ihrer medicinischen Anwendung, Berlin, Der Felishischen Buchhandlung, 1803 (Peitersen \& Zilstorff-Pedersen より引用)。34) 石川正：㴹路直流通電刺戟による筋 反応，日耳舅，62(3): 125, 1959. 35) Quix, F.H.: Ned. $T$ Geneesk, 70: 471 475, 1926. cited by Peitersen, E. \& Zilstorff-Pedersen, $\mathrm{K}^{28)}$ ). 36) Glorig, A. and Fowler, E.P.: Tests for labyrinth function following streptomycin therapy, Ann. Otol. 56: 379, 1947. 37) Richter, H.R. and Pfaltz, C.R.: Confin. neuro. 18:370, 1958 (前庭研究会抄绿, No. 753). 38) 本川弘一: 電気生理学, 岩波全黹, 153, 1954. 39) 内海貞夫, 他：ストレイン・ゲージ

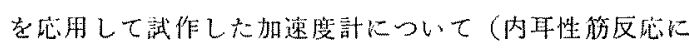
関主子研究)，共和技報，42号，253，1961.

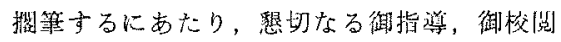
を睗つた恩師本庶正一教授に装心上り謝意を呅

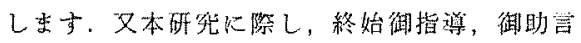
を睗つた本学生理学教室，丹生治夫教授，川端 五郎教授に染甚なる謝息を表します。あわせて 御助言を賜つた龂中兼男元助教授ならびに御场

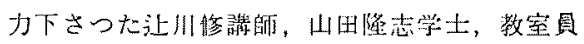
各位に媣く感謝します

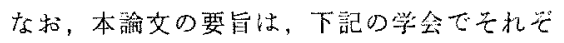

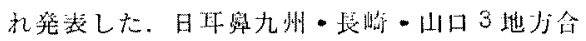

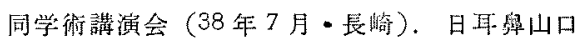
地方会 (38 年11月・田口). 日耳與第 65 回総

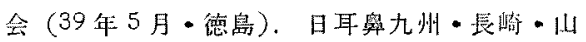
口3地方合同学丟 (39年6月・久留米).

（原秙到籍 $=$ 昭和 40.5 .31 日一急載） 